\title{
Трактовки и способы измерения продовольственной безопасности в современной России: дискурсивные и реальные противоречия
}

\author{
И.В. ТРОЦУК*, А.М. НИКУЛИН**, С. ВЕГРЕН***
}

\begin{abstract}
*Ирина Владимировна Троцук - доктор социологических наук, доцент, ведущий научный сотрудник, Центр аграрных исследований, Российская академия народного хозяйства и государственной службы при Президенте РФ; доцент, кафедра социологии, Российский университет дружбы народов. Адрес: 119571, Москва, просп. Вернадского, д. 82. E-mail: irina.trotsuk@yandex.ru

**Александр Михайлович Никулин - кандидат экономических наук, директор, Центр аграрных исследований, Российская академия народного хозяйства и государственной службы при Президенте РФ. Адрес: 119571, Москва, просп. Вернадского, д. 82. E-mail: nikulin@ranepa.ru

***С тивен Вегрен - профессор политологии, Южный методистский университет. Адрес: Dallas, Texas, 75275, USA. E-mail: swegren@smu.edu
\end{abstract}

Цитирование: Троцук И.В., Никулин А.М., Вегрен С. (2018) Трактовки и способы измерения продовольственной безопасности в современной России: дискурсивные и реальные противоречия // Мир России. Т. 27. № 1. С. 34-64. DOI: 10.17323/1811-038X-2018-27-1-34-64

В статье охарактеризованы форматы внимания политиков и ученых к проблемам продовольственной безопасности, особенно к ее противоречивым определениям в интеллектуальных и идеологических дискуссиях в связи с разработкой программ и доктрин продовольственной безопасности. Также отмечена важность концепичи продовольственного суверенитета как критически альтернативного ей подхода. Обращаясь к историческому и современному опыту обеспечения продовольственной безопасности в России, авторы отмечают зигзаги продовольственной политики - переход от советской автаркической модели продовольственного самообеспечения через попытки либерализации продовольственной политики 1990-х г2. к новой протекционистской и автаркической доктрине 2000-х г2. Критическому осмыслению в статье подвергаются индикаторы продовольственной безопасности: так, показатели валового роста производства разных видов продовольствия все же недостаточны для оченки начиональной продовольственной безопасности, поскольку ключевыми являются индикаторы эффективности аграрного производства, доступности качественных продуктов питания для всех слоев населения $u$ возможность потребителей контролировать вопросы продовольственного обеспечения. 
В заключительной части статьи представлен обзор сочиологических исследований продовольственной безопасности в России и прежде всего результатов мониторингов Центра аграрных исследований РАНХиГС в 2015-2017 годах, зафиксировавиих противоречивую «двойную автаркию» в ответах респондентов: с одной сторонь, они поддерживают политический курс на продовольственный протекционизм и национализм (автаркия государственная); с другой стороны, стремятся к продовольственному суверенитету (автаркия семейная), интенсифицируя натуральное самообеспечение.

Ключевые слова: продовольственная безопасность, либерализм, протекционизм, социальная дифференциация, доступность продовольствия, региональные различия

\section{Вариативность интерпретаций продовольственной безопасности}

Сегодня понятие «продовольственная безопасность» стало настолько общеупотребительным, что попытки оценить ее нынешний уровень и будущие перспективы предпринимаются не только официальными лицами и экспертным сообществом: рассуждать о необходимости пролонгации продовольственных антисанкций и эмбарго в национальных интересах страны готов, кажется, любой россиянин, не говоря уже о тех, кто связан с сельскохозяйственным производством. Однако частотность употребления не гарантирует понятию однозначности и единых контекстуальных рамок применения в научном, государственническом или обыденном дискурсах. Эта многоликость продовольственной безопасности объясняется в первую очередь тем, что она имеет целый ряд определений, акцентирующих ее весьма различающиеся аспекты [Kрылатых 2014, с. 3].

Во-первых, доминирующие в западной литературе трактовки в той или иной мере отражают принятое за основу на Всемирном продовольственном саммите в 1996 г. определение, которое гласит, что продовольственная безопасность - это состояние гарантированности физического (в месте проживания) и экономического (стоимость продуктов питания) доступа к достаточному количеству безопасной и питательной пищи для полноценного удовлетворения своих потребностей и ведения активного и здорового образа жизни [Вегрен, Троиук 2013], и оценивать степень его достижения призван Комитет по продовольственной безопасности ООН. Предпосылки подобной трактовки были заложены в 1970-е гг., когда стало очевидно, что начавшиеся даже в рамках одного государства продовольственные кризисы со временем неизбежно выплескиваются за национальные границы и обретают международный характер. Тогда появилось словосочетание «всемирная продовольственная безопасность», которое объединяет физиологические (потребности организма в определенном количестве элементов питания, допустимое содержание в продуктах вредных веществ) и экономические критерии (физическая и экономическая доступность продовольствия).

В 1990-е гг. это определение было дополнено глобальным измерением: поскольку в эпоху глобализации национальные экономики глубоко интегрированы в процессы мирового хозяйственного развития, то и продовольственная безопасность обретает характер глобальной проблемы (использования возможностей мирового рынка) и задачи (производства и/или закупки необходимого количества 
продуктов). В самом определении ничего не изменилось: это состояние, когда «люди на постоянной основе обладают физическими, социальными и экономическими возможностями получать достаточное количество безопасной и питательной пищи, соответствующей их потребностям и предпочтениям и необходимой для активного и здорового образа жизни» [World Development Report 2008, p. 94]. Однако стала акцентироваться проблема социального неравенства, порождающая ситуацию продовольственной опасности: Римская Декларация 1996 г. признала бедность основной причиной нехватки продуктов (значительное число людей слишком бедны и не в состоянии их покупать). Имеется в виду не только бедность в развивающихся странах: речь может идти о концентрации беднейшего населения в самых благополучных странах. Например, в 2012 г. более 14\% (17,6 млн) американских домохозяйств не имели достаточного доступа (денег или иных ресурсов) к продуктам, большая их часть сосредоточилась в сельских районах на юге страны, где по сравнению с городами уровень безработицы был выше, показатели зарплат - ниже, а количество магазинов, равно как и вариантов социальной поддержки, - меньше. Иными словами, «продовольствие - проблема домохозяйства, но ее решение обусловлено пространственными характеристиками социально-экономического неравенства», поэтому те, «кто выращивает нашу еду, страдают от голода и находятся в состоянии продовольственной опасности» [Piontak, Schulman 2014, p. 76].

В целом зарубежные трактовки продовольственной безопасности концентрируются на необходимости борьбы с голодом, недоеданием, низким качеством и недоступностью продовольствия, а не на продовольственной независимости национальных экономик. Поэтому множество обследований сосредоточено на развивающихся странах, где остро стоят проблемы голода и недоедания [Global Food Security Index 2015 , р. 12], и основной их причиной считается низкий уровень доходов населения, особенно в сельской местности. Обращение к проблеме бедности позволило уточнить трактовку продовольственной безопасности: это, скорее, континуум, чем набор точек, в разной степени отдаленных от идеальной ситуации продовольственной безопасности [Hendriks 2015]. Но критерии ее оценки мало изменились, при том что в глобальных масштабах количество недоедающих людей в развивающихся странах стало сокращаться - с 908 млн в 2000 г. до 780 в 2016 г.; в развитых странах 21 и 15 млн соответственно [The State of Food Insecurity 2015, p. 8].

Далее мы переходим ко второй проблеме, затрудняющей однозначную трактовку продовольственной безопасности в России: отличительной чертой ее интерпретаций, несмотря на их заимствованный характер, является ориентация, в первую очередь, на продовольственное самообеспечение и импортозамещение [Киселев 2013, с. 8]. Россия заняла протекционистскую позицию, считая необходимым наращивать ассортимент и масштабы производства продовольствия до тех пор, пока не будет достигнуто самообеспечение и продовольственная независимость. Причем Россия выбрала жесткий вариант протекционизма - не продовольственный суверенитет (самообеспечение отечественными продуктами высокого качества), но жесткий контроль объемов импорта продовольствия.

Третья проблема трактовки продовольственной безопасности - наличие близкого ей понятия «продовольственный суверенитет» [Виссер, Мамонова, Споор, Никулин 2015]. Это словосочетание редко встречается в российском дискурсе и используется как синоним продовольственной безопасности - гарантий самообеспечения посредством поддержки крупных сельхозпроизводителей. 
В западной литературе продовольственный суверенитет имеет и критические коннотации в духе идеологии крестьянских движений [Patel 2009], призывающих к радикальной демократизации сельхозпроизводства и протестам против экономической (и аграрной) политики Всемирного банка и крупнейших мировых экономик. В этом случае продовольственный суверенитет выступает как цель социальных движений, которые формируют устойчивый дискурс о нем и воплощают его в жизнь посредством коллективных действий [Declaration of Nyéléni 2007; Claeys 2013]. В России критически-активистская трактовка продовольственного суверенитета не используется по объективной причине ограниченного пространства для коллективной низовой мобилизации и политического действия социальных движений ${ }^{1}$, тогда как в зарубежной практике речь идет не только о глобальных движениях типа Виа Кампесины, но и о локальных формах сопротивления расширению глобальной продовольственной системы [Ayres, Bosia 2011], что дает основания говорить не о разных трактовках продовольственного суверенитета (нейтральной и критической), а о «множественных суверенитетах» [McMichael 2009].

И, наконец, диспут о российской продовольственной безопасности смещен из экономической плоскости в сферу (гео)политических дискуссий в русле риторики национальной безопасности. Одни авторы оценивают подобный крен негативно, другие - позитивно, мы же считаем, что его следует принять как данность, способную порождать продуктивные контексты постсоветского государственно-идеологической дискуссии о продовольственном обеспечении. Аналогичные споры важны и для европейского общества, хотя они и не получили столь же развернутого нормативного оформления, как в России, где продовольственная безопасность считается предпосылкой национальной безопасности ${ }^{2}$ в формате решения конкретных социально-экономических задач. Такую трактовку разделяют и многие члены научного сообщества, отрицающие, что «национальная продовольственная безопасность» - чисто экономическая категория, а не государственническая, считая, что она может противоречить экономической целесообразности [Фомичев, Ковиов 2010].

Доктрина продовольственной безопасности (2010 г.) зафиксировала разноречивые акценты в социально-экономической повестке российского руководства: с одной стороны, сохранилась ориентация на продовольственное самообеспечение (независимость от импорта) посредством наращивания объемов собственного производства; с другой стороны, в духе международных документов подчеркивалась необходимость обеспечения высокого качества отечественного продовольствия и его доступности - экономической и физической. Тем не менее до сих пор «при обсуждении продовольственной безопасности на первое место ставят вопросы производства необходимого объема продовольствия внутри страны, а не обеспечения физического и экономического доступа населения к продовольствию» [Шагайда, Узун 2015, с. 6]. Впрочем, речь идет именно об акцентах, потому что в Доктрине прописаны контрольно-целевые показатели (пороговые значения)

\footnotetext{
1 В частности, россияне предпочитают традиционные советские практики ведения личных подсобных хозяйств (ЛПХ) и ресурсы неформальной экономики в духе «оружия слабых» [Scott 1985].

2 См.: ФЗ «О продовольственной безопасности РФ» от 04.07.1996 г.; Указ Президента РФ от 12.05.2009 г. № 537 «О стратегии национальной безопасности РФ до 2020 года»; Доктрина продовольственной безопасности РФ, утвержденная Указом Президента РФ от 30.01.2010 г. № 120 и др.
} 
самообеспечения страны по отдельным видам продовольствия ${ }^{3}$, однако понятия «качество» и «доступность» продовольствия не получили четкого количественного описания, поскольку Доктрина - это нормативно-стратегический документ.

Новый виток российских дискуссий о продовольственной безопасности в контексте проблем национальной безопасности вызвало вступление России во ВТО [Барсукова, Коробкова 2014]: до 2012 г. количество отсылок к ВТО коррелировало с успешностью вступления России в ВТО, а в 2009-2010 гг., когда государство провозгласило курс на продовольственную безопасность в духе независимости, число упоминаний ВТО в прессе резко сократилось. Введенное российским правительством в 2014 г. продовольственное эмбарго усилило в политическом дискурсе и общественном мнении верность курсу на самообеспечение: в данной ситуации возобладали экономический национализм и продовольственный протекционизм, что свидетельствовало об отходе от либерального курса, одного из условий вступления в ВТО.

С середины $1990-$ х гг. ${ }^{4}$ российское руководство трактовало продовольственную безопасность как национальный приоритет и оценивало ее через объемы импорта продовольствия и его стоимость [О мониторинге и состоянии продовольственной безопасности 2012; Алтухов, Вермель 1997, с. 21]. Позже, в 2000-е гг., эта обеспокоенность только окрепла: в 2009 г. Д.А. Медведев назвал высокую зависимость страны от западных поставок мяса и птицы опасной5 нята Стратегия национальной безопасности РФ, где говорилось о необходимости сокращения зависимости от импорта и наращивания собственного производства; в 2010 г. - Доктрина продовольственной безопасности с указанием, что «самообеспеченность продовольствием - один из ее краеугольных камней» ${ }^{6}$. Своеобразную точку в дискуссиях поставил В.В. Путин в послании Федеральному собранию в декабре 2012 г.: «В ближайшие четыре-пять лет мы должны полностью обеспечить себя основными видами продовольствия, затем Россия должна стать крупнейшим в мире поставщиком продуктов питания» [Послание Президента 2012]. Попробуем разобраться, насколько Россия справляется с решением этих амбициозных задач.

\section{Подходы к оценке продовольственной безопасности}

Российская нормативная база воспроизводит основные идеи международных документов об обеспечении населения безопасным и питательным продовольствием в необходимых количествах, однако политические элиты страны постоянно подчеркивают необходимость преодоления зависимости от импорта за счет наращивания объемов собственного производства, что порождает попытки оценивать продовольственную безопасность через ее обеспеченность собственной продукцией. Впрочем, в обоих случаях используются статистические данные, несмотря

\footnotetext{
3 Например, к 2020 г. производить не менее $85 \%$ мяса и мясопродуктов, в 1,5 раза увеличить производство молока, мяса и овощей и т.д.

4 В тот период крупнейшие российские города импортировали около $70 \%$ продуктов питания.

5 Газета «Сельская жизнь». 25.06-1.07.2009 г.

6 Газета «Сельская жизнь». 4-10.02.2010 г.
} 
на ограничения статистического подхода (слишком много показателей, их сложно точно рассчитать, оценить их достоверность и использовать в сопоставлениях), поэтому очевидна необходимость дополнить их социиологическим мониторингом для оценки экономической доступности продуктов с учетом реальных продовольственных практик и предпочтений населения.

Итак, каковы основные варианты статистической оценки продовольственной безопасности? Прежде всего, это мониторинги, которые проводят международные организации для сравнительной оценки динамики продовольственной безопасности в разных странах. Так, аналитическая группа журнала The Economist paзработала Глобальный индекс продовольственной безопасности, используя 36 показателей, объединенных в три группы: (1) экономическая доступность продовольствия; (2) физическая доступность; (3) безопасность и качество [Global Food Security Index 2016]. Позиции России в индексе выглядят несколько странно, что предсказуемо, учитывая эмпирические индикаторы по каждой группе оценок: среди вошедших в 2016 г. в индекс 113 стран Россия заняла 48 место, несколько ухудшив свои позиции по показателям Глобального индекса, безопасности и качества продовольствия (рисунок 1).

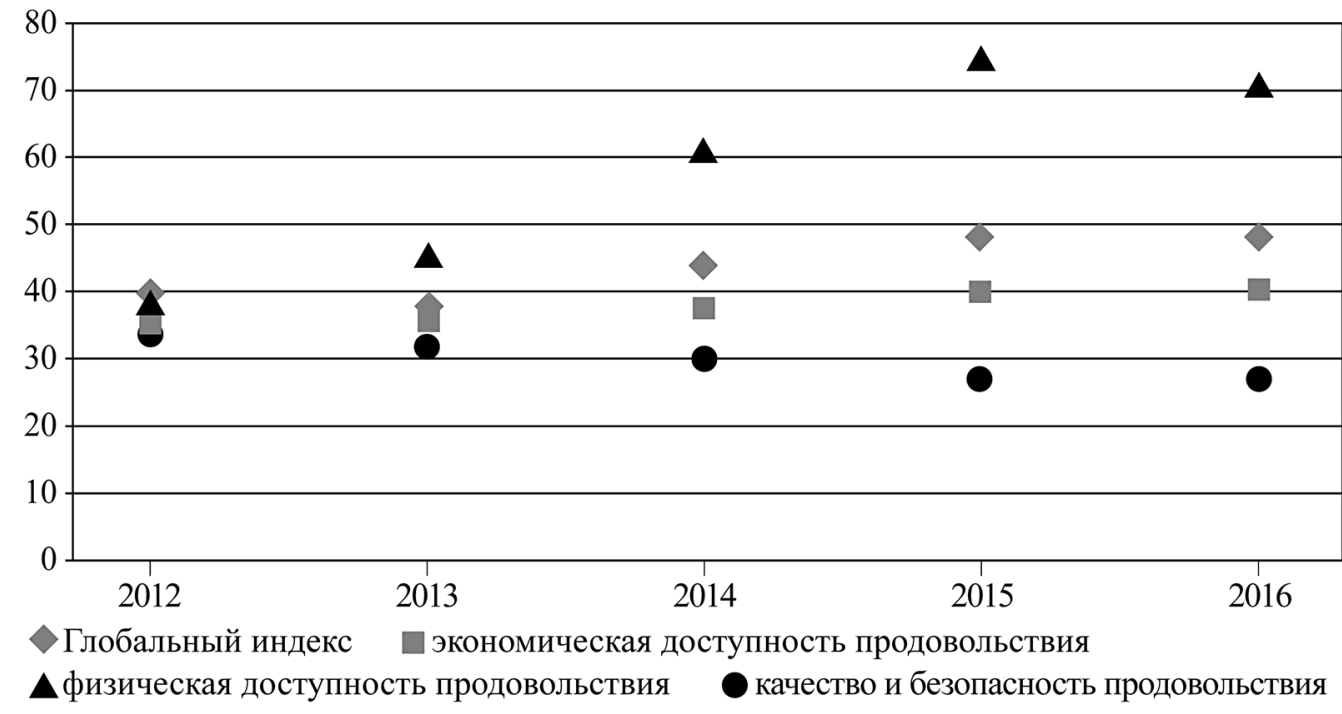

Рисунок 1. Россия в Глобальном индексе продовольственной безопасности

Следует отметить, что принятие Доктрины продовольственной безопасности сопровождалось разработкой системы мониторинга в формате четырех основных групп целевых показателей: (1) рациональные нормы потребления продуктов (на чел. в год); (2) нормы физиологической потребности в энергии и пищевых веществах (на чел. в сутки); (3) пороговые значения продовольственной независимости по отдельным продуктам; (4) нормативы обеспеченности товарными площадями населения субъектов РФ (в метрах на 1000 чел.) [О перечне показателей 
в сфере обеспечения продовольственной безопасности 2013]. Очевидно, что работа со столь большим количеством показателей затруднительна (не говоря уже о последнем показателе, мало что говорящем о реальной физической доступности продуктов), но и этот список не включает в себя важнейший показатель - экономическую доступность продовольствия. Мы не будем останавливаться на проблемах оценки продовольственной безопасности по приведенным показателям ${ }^{7}$, а обозначим лишь статистический контекст предлагаемого социологического мониторинга, учитывающего потребительские практики и предпочтения населения, поскольку важно понимать, насколько потребление основных продуктов питания соответствует рациональным нормам [Об утверждении рекомендаций по рациональным нормам 2016]. Согласно рисункам 2 и 3, по данному показателю население находится в относительной продовольственной безопасности [Потребление основных продуктов питания 2016], хотя потребляет недостаточно овощей, фруктов и ягод, молочных продуктов, но избыточно - сахара и растительного масла 8

Если оценивать продовольственную безопасность с точки зрения потребления основных продуктов питания, то в значительной степени она была обеспечена еще в советский период, хотя с некоторыми оговорками: так, калорийность продуктов в рационе горожан превышала международный минимум, однако была ниже продовольственного потребления в развитых странах Запада [The Soviet Agro-Food System 1991]. Кроме того, доступность продовольствия определялась не столько запросами потребителей, сколько расчетами центральных плановых структур, что неизбежно вело к дефициту одних товаров (мяса) и изобилию других (хлеба, яиц и картофеля). Типичный рацион советского потребителя включал в себя больше углеводов и крахмала, но меньше белка, хотя к 1980-м гг. среднее потребление мясопродуктов превысило показатели ряда западных стран, но в этой ситуации необходимо учитывать региональные различия внутри многонациональной страны, народы которой отличались и пищевыми практиками.

В советской продовольственной системе было немало ограничений, которые касались неравенства доступа к продуктам питания. Ее характерной чертой стал постоянный дефицит продуктов, особенно в средних и малых городах, который породил стереотипное восприятие советского прошлого как состоящего из хронического дефицита и очередей [Willis 1985]. Кроме того, в декларативно эгалитарной системе наблюдались «очаги» бедности (в советской терминологии речь шла о «малообеспеченных слоях населения»), которая, по оценкам западных ученых, составляла в России около 5\% [Matthews 1986; Silverman, Yanowitch 2000]. Эти группы пребывали в продовольственной опасности не в западном смысле (голода), а с точки зрения несоответствия установленным правительством нормам потребления, гарантирующим здоровый образ жизни. Кроме того, не следует забывать и о том, что статистика не учитывала качество продуктов.

В 1990-е гг. постсоветская Россия пережила тяжелейший экономический период, который не мог не ввергнуть миллионы людей в состояние продовольственной опасности. Согласно официальной (!) статистике, в конце 1990-х гг. более 40 млн россиян жили за чертой бедности [Социально-экономические индикаторы 2009].

\footnotetext{
7 Подробнее см. [Шагайда, Узун 2015].

8 По показателям сахара и растительного масла проблема может состоять в самой системе статистического учета.
} 


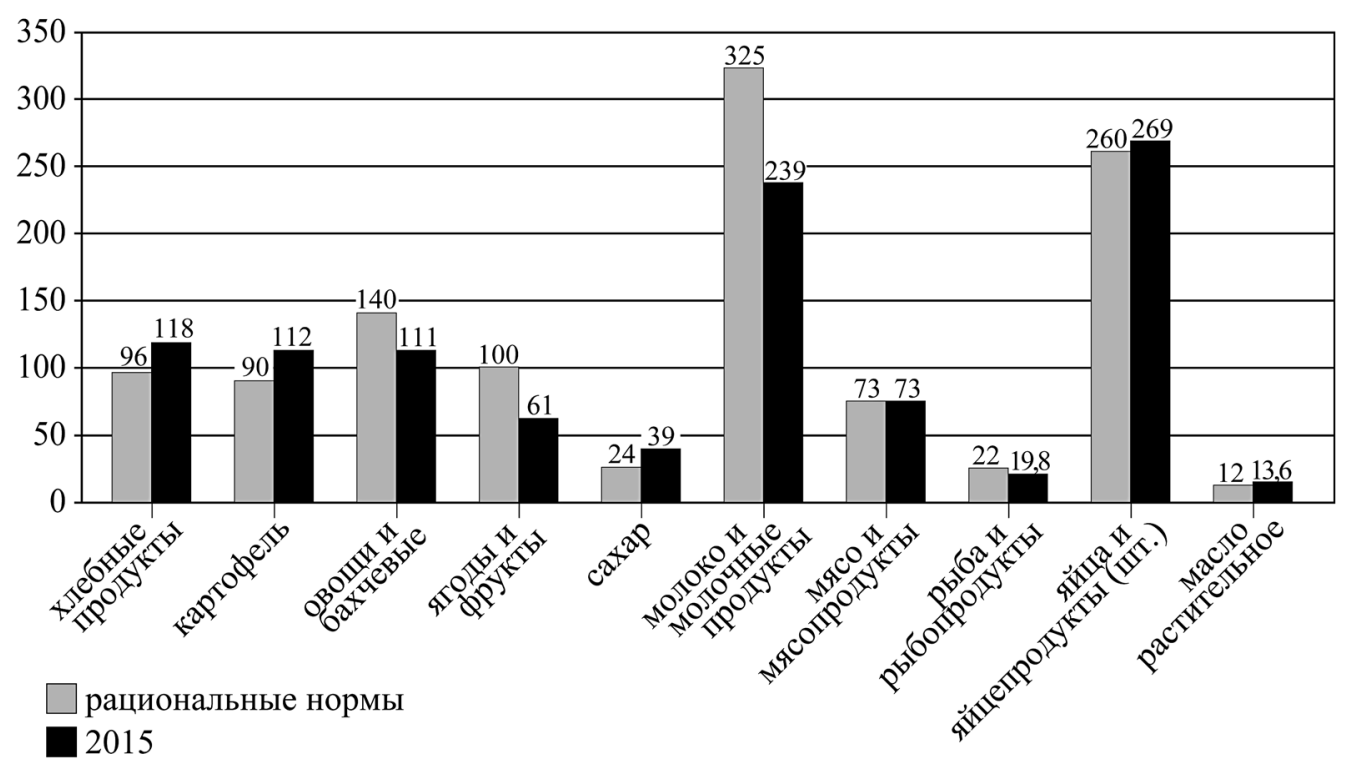

Рисунок 2. Потребление основных продуктов питания и рациональные нормы, кг на чел. в год, 2015 г.

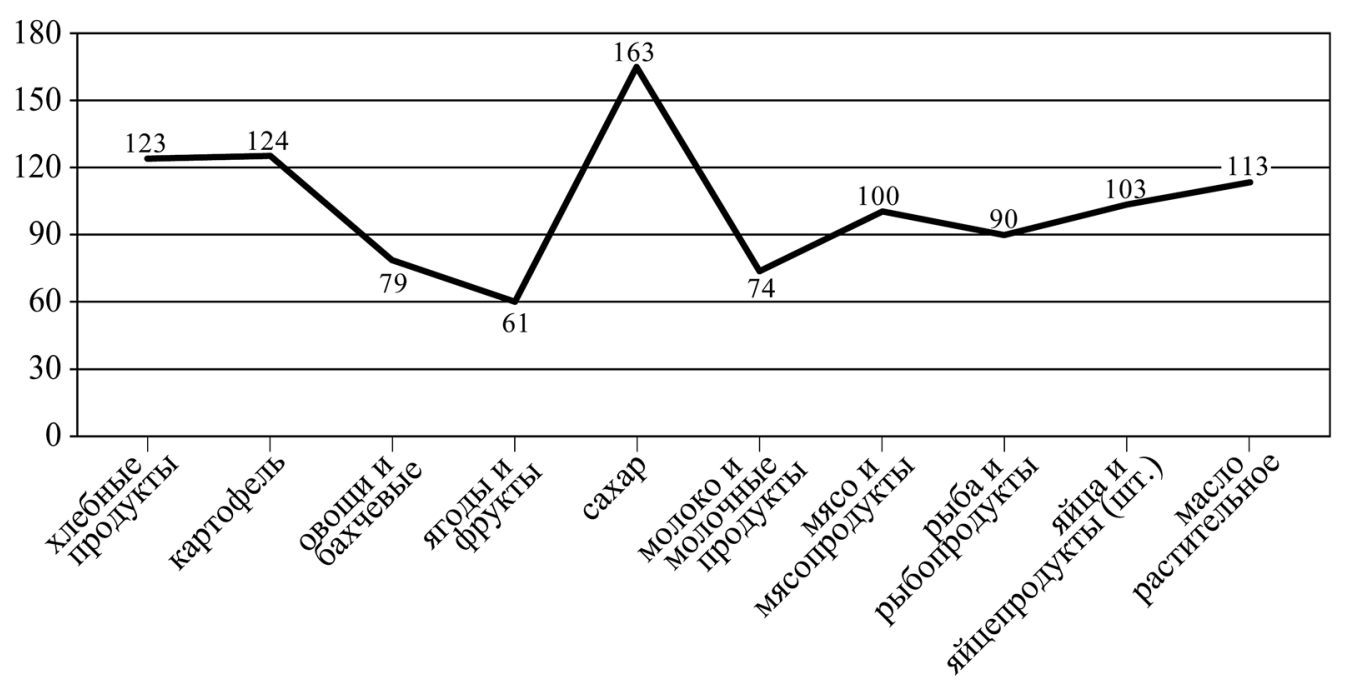

Рисунок 3. Соотношение потребления и рациональных норм, \%, 2015 г.

Также значительно сократилось производство на крупных сельхозпредприятиях, которые отвечали за снабжение продовольственных магазинов, что потребовало компенсации дефицита ростом импорта. Беднейшие горожане оказались в самом сложном положении и потребляли примерно половину ежедневного объема калорий, который по международным стандартам был индикатором голода [Sedik, 
Sotnikov, Weismann 2003, с. 41]. К середине 1990-х гг. продовольственное потребление горожан также было ниже установленных правительством норм по всем продуктовым категориям [Бондаренко 1998, с. 38]. К 1998 г., когда продовольственный розничный товарооборот составил около половины уровня 1991 г. [Овчарова, Бирюкова, Тер-Акопов, Барданян 2014, с. 18], горожане были вынуждены искать альтернативы продуктовым магазинам: одной из стратегий выживания стало самообеспечение (выращивание овощей и фруктов на огородах), вследствие чего размеры ЛПХ увеличились с 3,2 млн га в 1990 г. до 6,4 млн в 1998 г., а доля домохозяйств в производстве продуктов питания возросла с 26 до 57\% [Сельскохозяйственная деятельность 1999, с. 16, 18]. Второй стратегией выживания горожан стало изменение рациона: в 1991-1996 гг. в среднем калорийность питания сократилась на 16\% против 9\% у сельских жителей [Бондаренко 1998, с. 39], и только в 2000-е гг. ситуация изменилась к лучшему.

Как правило, в кризисные периоды в России возрастает производство (и потребление) собственного продовольствия, произведенного в ЛПХ сельскими жителями и горожанами на дачных участках. Однако в 2014-2016 гг. доля сельхозпродукции, производимой в хозяйствах населения, сократилась, поскольку продукты питания (за исключением картофеля и отчасти овощей) россияне преимущественно покупали в магазинах (таблица 1).

Другой важный статистический показатель, который имеет приоритетное для российского руководства значение, - достижение целей Доктрины, которое оценивается по показателям удельного веса отечественной продукции в общем объеме товарных ресурсов внутреннего рынка. Согласно рисунку 4 (см. на стр. 44), составленному по данным Росстата, критерии продовольственной безопасности достигнуты по всем основным группам продуктов, кроме молока. Благодаря стабильным темпам роста сельхозпроизводства соотношение импорта и собственного производства продовольствия в России улучшилось (с точки зрения сокращения импортозависимости). Впрочем, нужно принимать во внимание не только введение продовольственного эмбарго, но и девальвацию рубля, поскольку запрос рынка на определенные продукты сегодня удовлетворяется не менее успешно, чем до введения антисанкций, заменой поставщиков на тех, которые не вошли в санкционный список. Однако нельзя не признать, что российские сельхозпроизводители к концу 2016 г. заместили существенную часть прежде импортируемой продукции (кроме говядины).

Хотя в целом продовольственное эмбарго и не повлияло критическим образом на физическую доступность продовольствия для большинства российских потребителей, в силу ограниченности семейных бюджетов сложившаяся ситуация сказалась на экономической доступности продуктов: проблема состояла не в запрете импорта, а в том, способны ли члены домохозяйств питаться в принципе нормально отечественными или импортными продуктами. Согласно статистике, в 2014 г. в среднем домохозяйства тратили на продукты питания до $29 \%$ семейного бюджета, в 2015 г. - 32\% [Потребление продуктов 2015, с. 12], однако цифры серьезно варьируют в зависимости от уровня доходов, количества детей и места жительства. Согласно данным наших телефонных опросов, городские домохозяйства ответили на рост цен на продукты сокращением покупок (87\% самых бедных горожан) или приобретением более дешевых продуктов [Wegren, Nikulin, Trotsuk 2017] (таблица 2, см. на стр. 44). Вновь подчеркнем, что речь идет об оценках только количества продуктов питания, а не их качества. 
Таблица 1. Потребление продуктов питания, 2015 г.

\begin{tabular}{|c|c|c|c|}
\hline Продукты & Все домохозяйства & В городе & На селе \\
\hline \multicolumn{4}{|c|}{ Покупки, кг в год на человека } \\
\hline Хлеб и хлебные продукты & 85,6 & 78,6 & 105 \\
\hline Картофель & 28,5 & 31,8 & 19 \\
\hline Овощи и бахчевые & 66,3 & 71,3 & 52,2 \\
\hline Фрукты и ягоды & 56,9 & 62,2 & 42 \\
\hline Мясо и мясные продукты & 70,6 & 74,6 & 59,3 \\
\hline Молоко и молочные продукты & 237 & 248 & 204 \\
\hline Яйца, штук & 182 & 200 & 132 \\
\hline Рыба и рыбные продукты & 16,7 & 16,9 & 16,1 \\
\hline Сахар и кондитерские изделия & 31,1 & 28,3 & 38,9 \\
\hline Масло растительное и другие жиры & 10 & 9,3 & 11,9 \\
\hline \multicolumn{4}{|c|}{ Доля натуральных поступлений в общем потреблении, \% } \\
\hline Хлеб и хлебные продукты & 0,8 & 0,6 & 1,2 \\
\hline Картофель & 48,3 & 36,9 & 72 \\
\hline Овощи и бахчевые & 30,7 & 24,1 & 48,2 \\
\hline Фрукты и ягоды & 15,2 & 11,5 & 27,5 \\
\hline Мясо и мясные продукты & 7,2 & 3 & 19,6 \\
\hline Молоко и молочные продукты & 4,5 & 1,2 & 14,1 \\
\hline Яйца, штук & 12,9 & 4,8 & 35,9 \\
\hline Рыба и рыбные продукты & 8,7 & 6,1 & 15,3 \\
\hline Сахар и кондитерские изделия & 6 & 5 & 8 \\
\hline Масло растительное и другие жиры & 1 & 0 & 1,7 \\
\hline
\end{tabular}

Источник: [Потребление продуктов питания 2016]. 


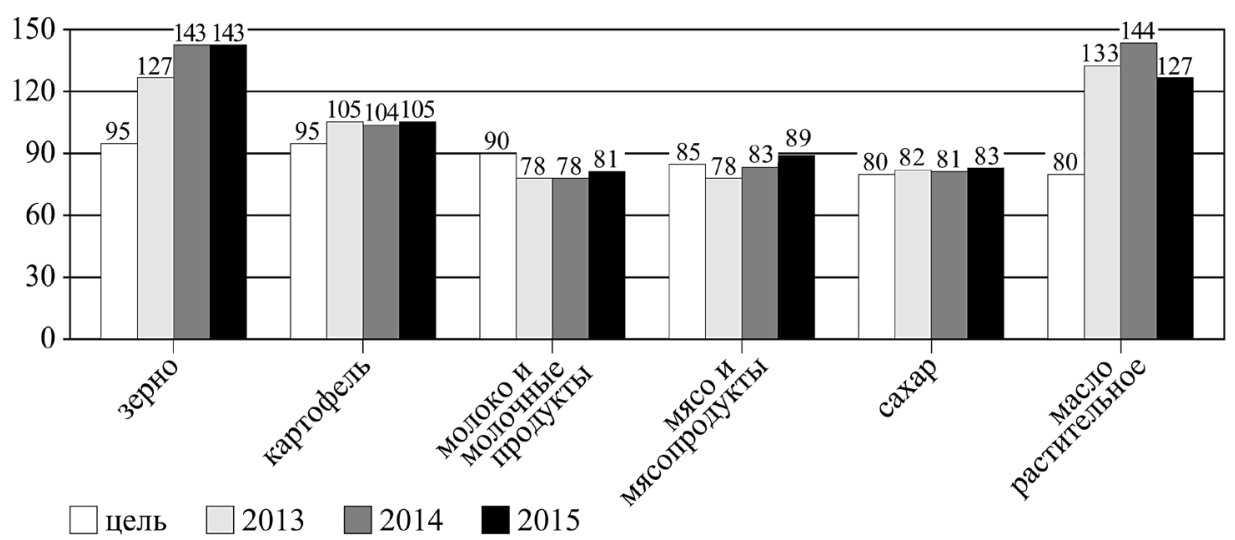

Рисунок 4. Продовольственное самообеспечение, \%

Таблица 2. Доступность продуктов питания для городских потребителей, \%, 2016-2017 гг. (соотношение уровня доходов и ответов на вопрос «Исчезли ли в этом году с прилавков какие-либо продукты питания, которые Вы обычно покупали?»)

\begin{tabular}{|l|c|c|}
\hline \multirow{2}{*}{ Уровень доходов } & \multicolumn{2}{|c|}{ Нет, не исчезли } \\
\cline { 2 - 3 } & $\mathbf{2 0 1 6}$ г. & $\mathbf{2 0 1 7}$ г. \\
\hline Ниже уровня бедности (<10 тыс. руб. в месяц) & 83 & 68 \\
\hline Низкий (11-30 тыс. руб. в месяц) & 89 & 83 \\
\hline Средний (31-50 тыс. руб. в месяц) & 87 & 84 \\
\hline Выше среднего (51-100 тыс. руб. в месяц) & 77 & 82 \\
\hline Высокий (более 100 тыс. руб. в месяц) & 56 & 78 \\
\hline В целом по выборке & $\mathbf{8 6}$ & $\mathbf{8 2}$ \\
\hline
\end{tabular}

Основным показателем экономической доступности продовольствия является удельный вес расходов на питание в семейном бюджете: если он не превышает $20 \%$, то можно говорить об экономической доступности; если расходы превышают пятую часть, но составляют менее трети бюджета, то уровень доступности продовольствия средний; более одной трети, но менее половины - высокий, а свыше $50 \%$ - критический (ситуация в российском обществе в кризисные 1990-е гг.). Хотя, согласно статистике, доля затрат сельского населения на продовольствие превышает аналогичные показатели городского населения, в обеих подгруппах расходы на питание все же укладываются в пределы среднего уровня [Доходы, расходы и потребление 2016].

Таким образом, в оценках продовольственной безопасности доминируют экспертные суждения на основе данных экономической статистики, т.е. макрооптика. Она позволяет исследователям утверждать, что российское руководство предпочитает политические решения в этой области, придерживаясь идеологии экономического национализма (противоположности либерализма, свободной торговли и 
международной интеграции), сочетая ее с разными формами государственного вмешательства в экономику. Для легитимации этой идеологии нередко привлекаются данные социологических опросов, которые тяготеют к оценке общественного восприятия государственных решений и их последствий в сфере продовольственной безопасности, а немногочисленные проекты в рамках качественного подхода фиксируют, скорее, типовые стратегии выживания сельских домохозяйств, которые, с одной стороны, примерно на $20 \%$ обеспечивают себя сами мясной и молочной продукцией, но, с другой стороны, наиболее подвержены бедности, и риск обнищания возрастает с уменьшением населенного пункта, т.е. эти проекты не ориентированы на оценку устойчивых поведенческих паттернов населения в сфере продовольственного (само)обеспечения. Например, в марте 2015 г. Фонд «Общественное мнение» (ФОМ) провел анализ потребительского поведения россиян в условиях кризиса [Потребительское поведение россиян в условиях кризиса 2015]: с начала года 39\% населения стали покупать более дешевые продукты (в 2017 г. - каждый третий), 31\% отказался от покупки некоторых продуктов (в 2017 г. - каждый пятый), 29\% покупали продуктов меньше (в 2017 г. - каждый пятый), 15\% реже ходили за покупками (в 2017 г. - 13\%), видимо, отказываясь от закупок впрок и приобретая по мере необходимости в небольших количествах только то, что планируется использовать в ближайшее время. Более половины россиян стали экономить на продуктах питания: треть - на мясе, птице, сыре и колбасе, каждый четвертый на фруктах, рыбе и морепродуктах, каждый десятый - на молочной продукции. ФОМ продолжает отслеживать эти показатели в мониторинговом режиме, проводя замеры в среднем три раза в год - весной, летом и осенью: с начала 2015 г. основные статьи экономии россиян в продовольственном потреблении не менялись, хотя доли экономящих несколько сократились к началу 2017 г.: на мясе и птице - 32 и 24\% соответственно, на сыре и колбасе - 30 и $20 \%$ соответственно, на рыбе и морепродуктах - 25 и 16\% соответственно [Покупка продуктов и экономия 2017].

Близкие по тематике опросы выполняют и другие исследовательские компании. В апреле 2015 г. холдинг «Ромир» провел оценку адаптации россиян к условиям продовольственного эмбарго: более трети (37\%) заметили изменения в ассортименте магазинов; каждой пятой семье пришлось внести коррективы в продуктовую корзину; $12 \%$ семей перешли на альтернативные марки продуктов взамен исчезнувших (в основном это жители крупных городов с высоким доходом) [Милехин 2017]. В том же году Аналитический центр при Правительстве РФ представил данные, свидетельствующие, что продовольственное эмбарго привело к резкому скачку цен и снижению качества продукции: средние цены на говядину, свинину и сыр за год выросли на 20\%, на замороженную рыбу, морковь, яблоки - на 40\%, на крупы и бобы - на 50\%. Подобная ситуация сложилась ввиду точечной стимуляции антисанкциями роста производства продуктов [Продуктовое эмбарго привело к росту цен 2015]. По данным ВЦИОМ за 2015 г., запрет на ввоз продовольствия из стран, которые ввели санкции против России, поддерживало большинство россиян (73\% в ноябре 2015 г. и 84\% в августе 2014 г.); 63\% сочли контрсанкции продуктивной мерой, полезной для страны (в августе 2014 г. - 80\%) [Продовольственные контрсанкции России 2015]. Столь позитивное восприятие эмбарго, видимо, объясняется и тем, что большинство россиян $(87 \%)$ не заметило дефицита продовольствия, 64\% зафиксировали увеличение доли отечественных продуктов питания в магазинах, а каждый второй полагал, что произошел рост сельского хозяйства. 
Иными словами, в изучении продовольственной безопасности очевидны две проблемы. Во-первых, сложно оценить происходящие в данной сфере изменения, поскольку программы сбора данных практически не затрагивают вопросы экономической доступности продовольствия, устойчивых продовольственных практик населения и потенциальных рисков в области продовольственной безопасности. Во-вторых, наблюдается разрыв в данных эмпирических исследований: это либо точечные описания повседневных практик в отдельных типах поселений (региональные или сельские кейсы), либо опросы общественного мнения, по определению не учитывающие региональную и локальную специфику. Для преодоления этих проблем мы разработали модель комплексного социологического мониторинга продовольственной безопасности, которая включает в себя два типа данных и инструментариев: (1) телефонный опрос на общероссийской выборке; (2) полуформализованные экспертные интервью с сельхозпроизводителями и руководителями муниципального уровня в разных регионах, призванные наполнить массовый опрос реальным содержанием и уточнить скрывающиеся за абстрактными цифрами конкретные повседневные практики и проблемы. Будучи ограничены объемами статьи, мы кратко представим только результаты телефонных опросов, оставив вторую часть нашего проекта для будущих публикаций. Задачи опросов состояли в определении: (а) повседневных продовольственно-потребительских представлений и практик населения; (б) степени поддержки россиянами государственной риторики о необходимости продовольственного эмбарго и самообеспечения страны.

\section{Продовольственные практики населения, или экономическая доступность продуктов}

В 2015 г. мы апробировали собственный инструментарий мониторинга продовольственной безопасности: в ходе телефонного опроса были интервьюированы 1831 чел. в возрасте 18-92 лет в сельской местности и городах Алтайского, Краснодарского и Приморского краев; также были транскрибированы 12 самых длительных интервью с целью оценки семантики и аргументации ответов на вопросы9. Обозначенные регионы презентируют соответствующие макрорегионы России - европейский, сибирский и дальневосточный; каждый край является лидером макрорегиона по производству аграрной продукции; относительно друг друга, а также в целом среди субъектов РФ три региона по ключевым аграрным показателям сильно дифференцированы: Краснодарский край характеризуется наибольшими объемами сельхозпроизводства, Алтайский край - средними, Приморский край - наименьшими.

Инструментарий исследования включал в себя пять тематических блоков:

1) государственная политика (осведомленность о Доктрине, отношение к запрету импорта);

\footnotetext{
9 Исследование было проведено Центром аграрных исследований РАНХиГС и АНО «Социальная валидация» при финансовой поддержке Фонда Розы Люксембург (российский филиал) методом телефонного опроса на двухосновной выборке мобильных и стационарных телефонов посредством случайного генерирования номеров по спискам номерных емкостей, публикуемых Россвязью.
} 
2) покупка продовольствия (оценка изменений ассортимента в магазинах, ограничения в приобретении продовольствия и выбор мест покупок, действия в случае роста цен, критерии выбора продуктов);

3) цены (доля затрат на продукты в семейном бюджете, отношение к государственному регулированию цен);

4) характеристика домохозяйства (выращивание овощей и фруктов, помощь родственников, материальное положение);

5) социально-демографические характеристики респондента.

Опросный инструментарий был призван определить отношение населения к мерам Правительства по обеспечению продовольственной безопасности страны в режиме эмбарго ${ }^{10}$; выяснить мотивы потребительского выбора российских продуктов; оценить экономическую доступность продовольствия в условиях роста цен и снижения покупательной способности рубля; установить, обратилось ли население к традиционным стратегиям адаптации - ведению ЛПХ или созданию запасов.

Полученные данные подтвердили (а) недостаточность регионального анализа (необходимы общероссийские данные, тем более что ситуация по большинству параметров опроса оказалась схожей во всех регионах); (б) необходимость ухода от вопросов вне компетентности респондентов, порождающих предсказуемые в силу эффекта социальной желательности ответы (например, о поддержке Доктрины), в сферу продовольственно-потребительских практик, предпочтений и объективных возможностей. Приведем кратко результаты нашего первого регионального опроса: подавляющее большинство россиян (92\%) уверены в необходимости Доктрины (вопрос «На Ваш взгляд, нужна ли нашей стране доктрина продовольственной безопасности?»); $71 \%$ поддерживает отказ от импорта продуктов, т.е. введенные государством протекционистские меры; эта поддержка носит скорее стереотипно-традиционный характер, чем рационально мотивирована, поскольку большинство (66\%) ничего не слышали о Доктрине (вопрос «Слышали ли Вы о доктрине российского правительства по продовольственной безопасности?»).

Опрос подтвердил нашу гипотезу о продовольственном национализме: большинство населения (94\%) в ситуации потребительского выбора предпочитают российские продукты иностранным. В транскриптах интервью обнаружились и объяснения столь убежденного предпочтения отечественной продукции: так, одну из причин запрета импорта иностранных продуктов респонденты видят в их опасности для здоровья: «Обязательно надо запретить, потому что оттуда и болезни, $u<\ldots>$ всевозможные заражсения». Более того, импорт продуктов часто объясняется сознательным желанием западных держав подорвать здоровье граждан России и тем самым нанести стратегический урон стране: «Нужно запретить, нужно, обязательно нужно! Во-первых, это безопасность. Во-вторых, капиталистические страны стремятся уничтожсить нас как население вообще некачественными ГМОмными продуктами, чтобы у нас рождаемости не было, <...> чтобы мы поумирали побыстрее, а они бы захапали бы наши все полезные ископаемые». Можно снисходительно-иронично относится к подобным высказываниям, но они отражают бытующие в российском обществе стереотипы.

Впрочем, нельзя сказать, что россияне уверены в качестве отечественной продукции, о чем свидетельствуют ностальгические воспоминания о советских

10 Мы полагали, что в духе официального курса на импортозамещение и экономический национализм население будет поддерживает протекционистские меры. 
продуктах: «Если колбаса, так она мясом пахла, за ней очередь стояла.<... Сейчас я ее вообще перестала брать! Я боюсь: аппетит начинает баснословный из тебя прямо выходить, кидаешься на все, т.е. добавки такие добавляют страшные. И какое же здоровье? А дети какие у нас все толстые, безобразные! Сколько стало толстых людей из-за этого! < ...> Пусть продуктов будет меньше, но они пусть будут нормальныли, натуральными». Другой мотив отказа от покупки зарубежных продуктов - трактовка этого шага как формы поддержки политического курса руководства страны: «Обязательно надо ввоз запретить, $<\ldots>$ особенно от враждебных стран: Грузии, Украинь, Америки, - всех, кто против России, от тех строго надо запретить <..> ввозить продуктьл;; «Я бы чисто из вредности запретила, потому что нам все пакостят». Оттеняет негативные высказывания позитивная мотивация: запрет будет стимулировать отечественное производство: «Обязательно надо запретить! Это и нашу безопасность сохранит, и повысит занятость населения, безработица сократится. Два зайца убивается этим делом. У нас можно свои качественные продукты не хуже ихних производить».

При этом респонденты прекрасно понимают серьезные проблемы российского сельского хозяйства: «Корпорации гребут и тендеры, и зеленый свет у них везде. $<\ldots>$ Плюс, если сидит ешуе руководитель - губернатор или мэр, он подтягивает конкретно своих людей, которые под него прогиб делают. <...> Они выигрывают и тендера, и денежки, и все дела, <..> а маленький обыватель реально скребется и не может вылезти из этой утопической ситуации». Впрочем, данные высказывания встречаются реже, чем в той или иной форме выраженный продовольственный национализм: «я патриотка, я буду покупать отечественный продукт, даже если он будет чуть-чуть дороже, я все равно его куплю».

В основном опрошенные покупают продукты в магазинах - больших универсальных супермаркетах/гипермаркетах (61\%) или небольших (41\%), при этом почти каждый второй (46\%) ходит за продуктами на продовольственный рынок; из тех 5\%, кто выбрал вариант «другое», большинство (76\%) назвали оптовые базы. По мнению 43\% респондентов, там, где они живут, отечественных продуктов питания больше, чем импортных; противоположных оценок придерживается каждый пятый (21). Это, кстати, практически единственный вопрос анкеты, по которому прослеживаются региональные различия: жители Приморского края намного чаще видят на прилавках импортную продукцию (37\%) против примерно каждого десятого в двух других регионах (рисунок 5).

84\% опрошенных не зафиксировали исчезновения привычных продуктов с прилавков магазинов, но те, кто заметил, называли в основном молочные продукты (прежде всего сыр) и фрукты. Из-за роста цен ограничили себя в покупке продуктов 68\%, не ограничили - 31\%, причем затруднившихся ответить на этот вопрос почти не было (1\%). Из-за роста цен люди перестали покупать, в первую очередь, мясо (68\% ограничивающих себя в покупках), рыбу (51\%), овощи и молочные продукты (по 30\%). На момент опроса каждый третий тратил на продукты питания более 50\% семейного бюджета, более трети - 64\%; по сравнению с 2014 г. 79\% стали тратить на продукты больше денег, несмотря на то, что 64\% выращивали овощи и фрукты, а $22 \%$ держали птицу или скотину. Региональные различия здесь предсказуемо существенны: так, овощи и фрукты чаще выращивают жители Алтайского края (79\% против 55 и 60\% в Краснодарском и Приморском краях). 
«Как Вы думаете, каких продуктов питания там, где Вы живете, в продаже сейчас больше - отечественных или импортных?»

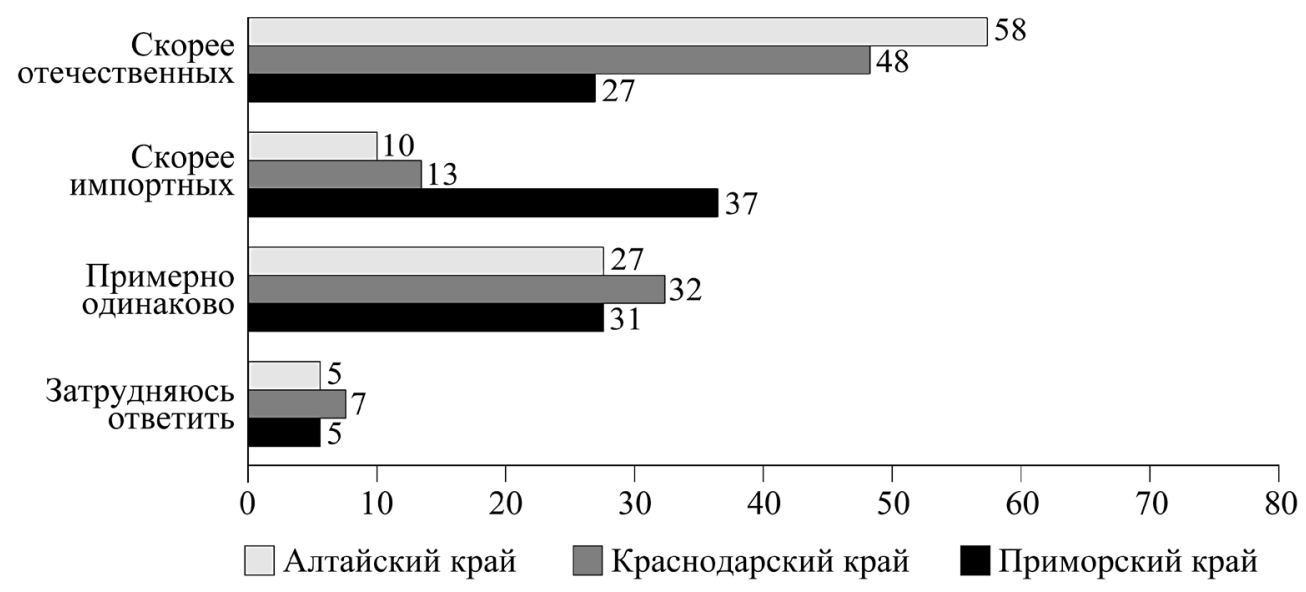

Рисунок 5. Региональные различия в розничной торговле, \%

В интервью часто звучали упреки в адрес недобросовестных ритейлеров, которые накручивают цены на продукты, и бороться с ними предлагается государству посредством жесткого регулирования цен на социально-значимые продукты (88\%): «Государство должно регулировать иены на продукты, потому что они во всем мире регулируются, потому что капиталистическая система - сильно алчная. Особенно у нас в России сильно много алчных людей, которые стараются нажиться на спекуляции»; "Государство просто обязано установить максимальную иену на основные продукты питания - молоко, хлеб, мясо, колбасы, сыры. $<\ldots>$ А по регионам дать указание губернаторам "если вы в состоянии сделать цену ниже для своих людей, которые у вас работают, сделайте меньше. Но если вы сделаете на копейку выше, мы вам сделаем секир-башка”»; “Сам человек, который работает на земле, получает гроши. То же молоко - они очень мало получают, а перекупшик берет больше половины иены. Это неправильно. Зарабатьвать должны в первую очередь те, кто производит. < ... > Государство должно исключить перекупшиков и ограничить их».

При дальнейшем росте цен 43\% респондентов постарались выращивать больше продуктов на огороде, а не делать запасы (7\%), видимо, потому что 80\% опрошенных оказывали помощь родственникам деньгами, продуктами или работой по хозяйству и, скорее всего, надеялись на взаимную поддержку (60\% уже получали помощь). Мотивы этой поддержки варьируют от традиционных до рациональных: «Если бы родственники не держались бы друг за дружку, наверное, совсем бы все плохо было»; "Помогаем всем своим родственникам, всем племянницам. Мы родителям, они - нам помогают. <..> Мы всем делимся. У нас нет такого: это мой мешок картошки, это твой. Mbl за то, чтобы у всех было». Из высказываний видно, что параллельно государственной политике продовольственной безопасности, которую население поддерживает, россияне воспроизводят традиционные стратегии самообеспечения за счет ЛПХ и взаимной поддержки. 
Как показали результаты нашего первого мониторинга, оптимальным форматом его проведения является сочетание количественных и качественных оценок дополнение статистических выкладок телефонного опроса анализом транскриптов интервью, в которых респонденты расшифровывают свой выбор вариантов ответов. Однако мы сочли необходимым расширить качественный блок мониторинга за счет полуформализованных интервью экспертного характера, чтобы наполнить реальным содержанием статистические и количественные социологические данные - информацией людей, которые в силу профессиональной занятости занимаются производством или распределением продовольствия в муниципальных образованиях или районах. Повторимся, что, будучи ограничены размером статьи, мы не можем представить данные экспертных интервью 2017 г. $^{11}$, тем более что полевой этап проекта продолжается (пока собраны данные на Кубани и в Оханском районе).

В 2016 г. $^{12}$ мы сократили инструментарий, оставив наиболее хорошо сработавшие и самые важные для нас вопросы и уточнив закрытия ряда вопросов, внеся в них те варианты, которые оказались наиболее частотными в варианте ответов «другое» (например, в список продуктов, которые люди стали покупать меньше, были внесены фрукты). В 2017 г. ${ }^{13}$ мы еще больше сократили анкету, отслеживая лишь базовые для нас показатели, в частности, был убран блок о государственной политике, поскольку на протяжении двух лет после введения эмбарго поддержка населением государственного протекционизма оставалась высокой. В 2016 г. $71 \%$ поддерживали ограничения импорта зарубежных продуктов, 62\% были уверены, что Россия должна вводить продовольственные санкции/антисанкции; внесение в формулировку вопроса о государственном регулировании цен варианта «все цены на продукты питания» привело к его выбору $72 \%$ опрошенных, тогда как «только цены на социально-значимый набор» отметили 24\%. Также из анкеты были убраны вопрос о том, где россияне приобретают продукты (преимущественно в больших универсальных магазинах - 70\%, реже на рынке - 38\% или в небольших магазинах - 36\%), и вопрос о том, каковы основные критерии выбора продуктов питания при покупке (срок годности - 58\%, цена - 48\%).

Итак, россияне оптимистично оценивают обеспеченность продовольствием в нынешних условиях санкций/антисанкций, в большинстве своем (свыше 80\%) полагая, что привычные продукты питания с прилавков не исчезли (рисунок 6, см. на стр. 52). Тем не менее 14\% в 2016 г. и 6\% в 2017 г. все же отметили исчезновение ряда продуктов: недостаток овощей зафиксировало примерно равное ко-

11 При определении регионов мы руководствовались двумя соображениями: во-первых, статистическими данными об уровне среднедушевых доходов; во-вторых, налаженными связями, которые позволили бы провести полуформализованные интервью без жесткого контроля и давления со стороны административных структур. В итоговый список регионов для проведения экспертных интервью вошли Московская, Нижегородская, Саратовская, Белгородская, Томская области, Краснодарский и Пермский края. В каждом регионе проводилось минимум 20 полуформализованных интервью. В качестве экспертов выступали (нынешние и бывшие) руководители сельхозпредприятий, фермеры, главы товарных ЛПХ и сельских администраций.

12 Исследование было проведено Центром аграрных исследований РАНХиГС и АНО «Социальная валидация» при финансовой поддержке Фонда Розы Люксембург (российский филиал) методом телефонного опроса на двухосновной выборке мобильных и стационарных телефонов. Выборка составила 3068 чел.; был проведен общероссийский опрос; построены три подвыборки (Республика Башкортостан, Белгородская область и Краснодарский край).

13 Исследование было проведено Центром аграрных исследований, Центром агропродовольственной политики РАНХиГС (директор - Н.И. Шагайда) и АНО «Социальная валидация» при финансовой поддержке РАНХиГС. Выборка составила 1800 чел. 
личество респондентов (16 и 18\% соответственно), доли отмечающих сокращение молочных продуктов и фруктов в 2017 г. снизились с 40 до 32\% и с 26 до 13\% соответственно, а доли опрошенных, указавших на уменьшение количества мясных и рыбных продуктов, наоборот, увеличились с 12 до 24\% и с 24 до $31 \%$ соответственно (рисунок 7, см. на стр. 52).

Отметим, что значительная доля россиян до сих пор ограничивает себя в покупке продуктов (рисунок 8, см. на стр. 53), хотя следует оговориться, что в 2017 г. мы изменили формулировку вопроса, убрав уточнение «из-за роста цен», что, видимо, снизило долю ограничивающих. В 2017 г. мы включили отдельный вопрос «Из-за чего ваша семья стала себя ограничивать в покупке продуктов питания?»: вариант «выросли цены» здесь доминирует (58\% тех, кто ограничивает) над вариантом «снижение доходов» $(23 \%)$. В основном сокращение потребления в группе респондентов, которых оно коснулось, затронуло мясные продукты (с 59 в 2016 г. до 67\% в 2017 г.), рыбные (с 53 до 49\% соответственно) и фрукты (с 46 до 40\% соответственно) (рисунок 9, см. на стр. 53).

Кстати, в 2016 г. мы не обнаружили существенных региональных колебаний ${ }^{14}$, несмотря на то, что данные по Башкортостану, Белгородской области и Краснодарскому краю по экономическим параметрам варьировались. Некоторые различия прослеживались лишь по ряду показателей: так, доля ограничивающих себя в покупке продуктов питания из-за роста цен в Белгородской области (76\%) превышала аналогичные характеристики в Краснодарском крае и Башкортостане (68 и 61\% соответственно), что неудивительно, поскольку белгородцы чаще обращали внимание на цену товара (54 против примерно 45\%). Также, в отличие от среднероссийского показателя, в трех регионах доля тех, кто приобретал продукты питания в крупных универсальных магазинах, оказалась выше (более 64\%), но по остальным показателям ситуация различалась: в Краснодарском крае столь же важное значение имел продуктовый рынок (61\%), в Белгородской области каждый второй ходил и на рынок, и в небольшие магазины. Впрочем, в случае дальнейшего роста цен жители трех регионов ориентировались в первую очередь на самообеспечение: каждый второй предполагал выращивать больше продуктов на огороде, а еще больше ограничить себя в покупке продуктов питания планировали жители Белгородчины и Краснодарского края (по 27\% против 18\% в Башкортостане).

Продовольственный национализм проявляется в ответах россиян с поразительной устойчивостью: большинство (свыше 86\%) предпочло отечественные продукты иностранным, если они будут одинаковы по цене. Проблема состоит в том, что стоимость продуктовой корзины не позволяет населению быть особенно избирательными, поскольку значительная часть россиян выделяет на продукты существенную долю семейного бюджета. Так, по самооценкам, если в 2016 г. каждый четвертый респондент тратил более половины семейного бюджета на продукты питания, а каждый третий - от 30 до 50\% (рисунок 10, см. на стр. 54), то в 2017 г. эти показатели выросли: примерно 49\% опрошенных расходовали на продукты питания свыше половины семейного бюджета (рисунок 11, см. на стр. 54) ${ }^{15}$.

\footnotetext{
14 Незначительные колебания укладываются в пределы статистической погрешности.

15 Самооценка доли расходов на продукты питания в семейном бюджете практически в два раза повышает долю бедных по сравнению с данными Росстата: 13,5\% россиян имеют денежные доходы ниже величины прожиточного минимума (см. [О соотношении денежных доходов населения 2016]).
} 
«Исчезли ли с прилавков какие-либо продукты питания, которые Вы обычно покупаете?»

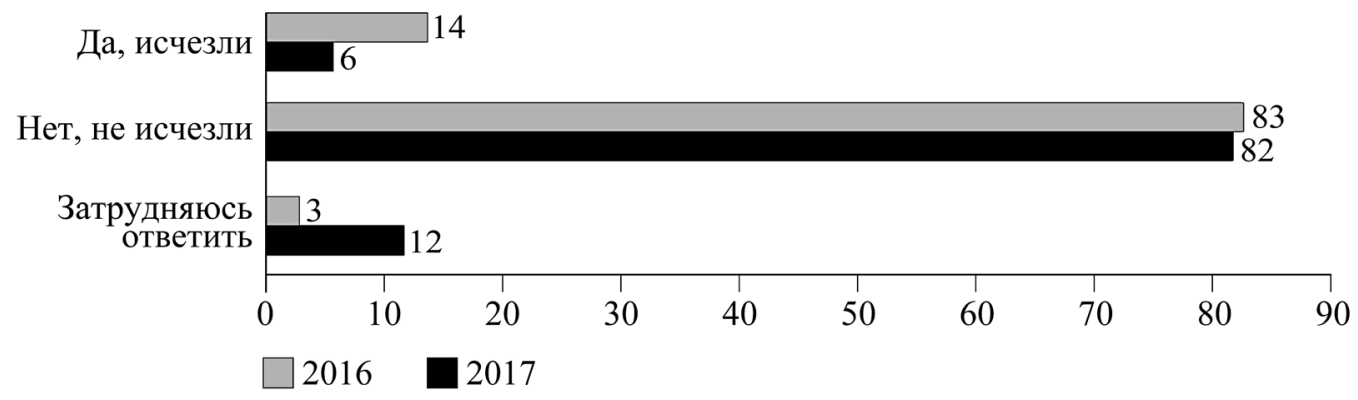

Рисунок 6. Сокращение продуктового ассортимента, \%

«Какие продукты питания, которые Вы обычно покупали, исчезли с прилавков: овощи, рыба, мясо, фрукты, молочные продукты или какие-то другие?»

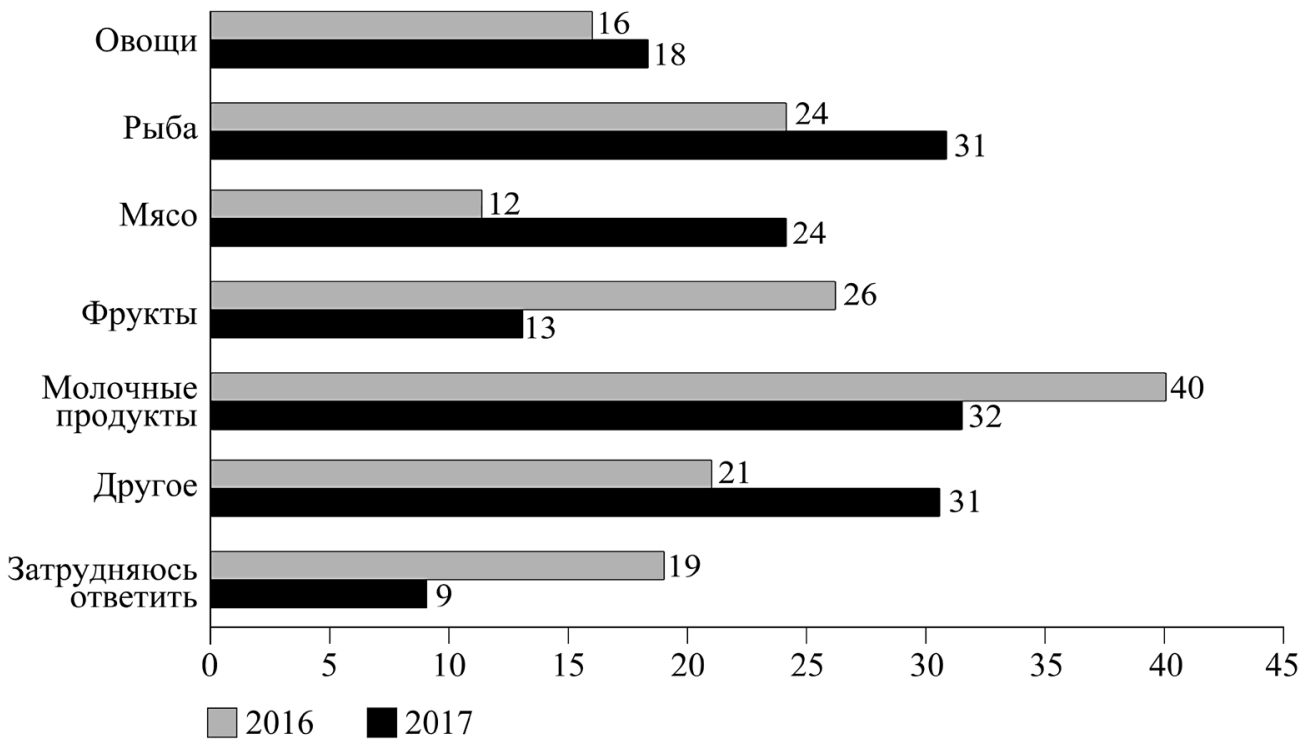

Рисунок 7. Продукты, пропавшие с прилавков, \% 
«Стала ли Ваша семья ограничивать себя в покупке продуктов питания?»

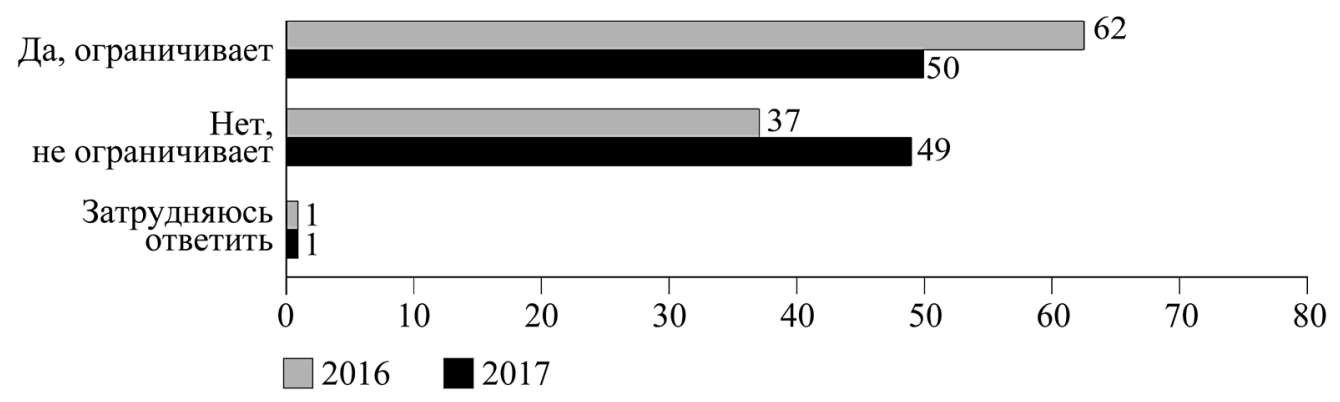

Рисунок 8. Ограничения в покупке продуктов питания, \%

«Какие продукты питания в семье стали покупать меньше?»

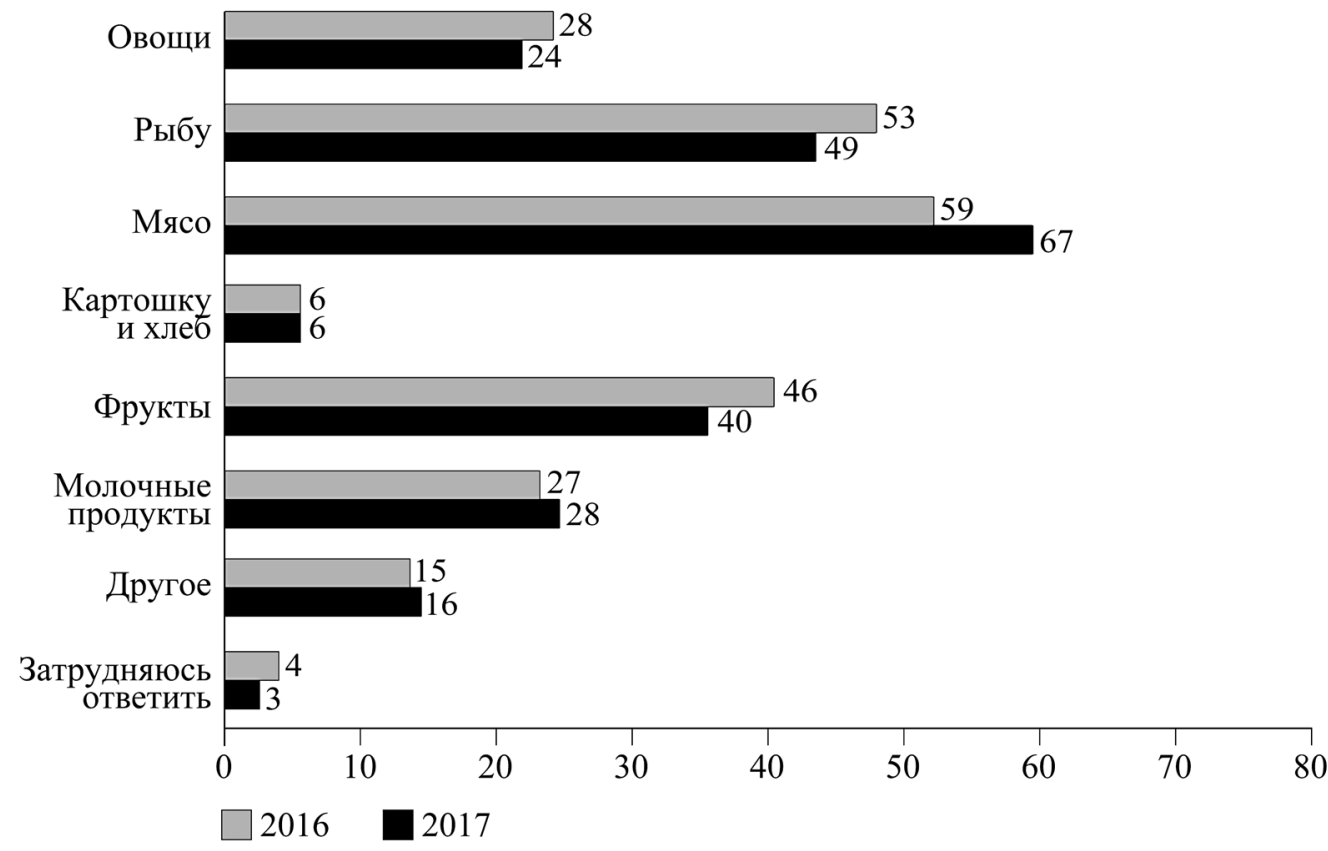

Рисунок 9. Сокращение потребительской корзины, \% 


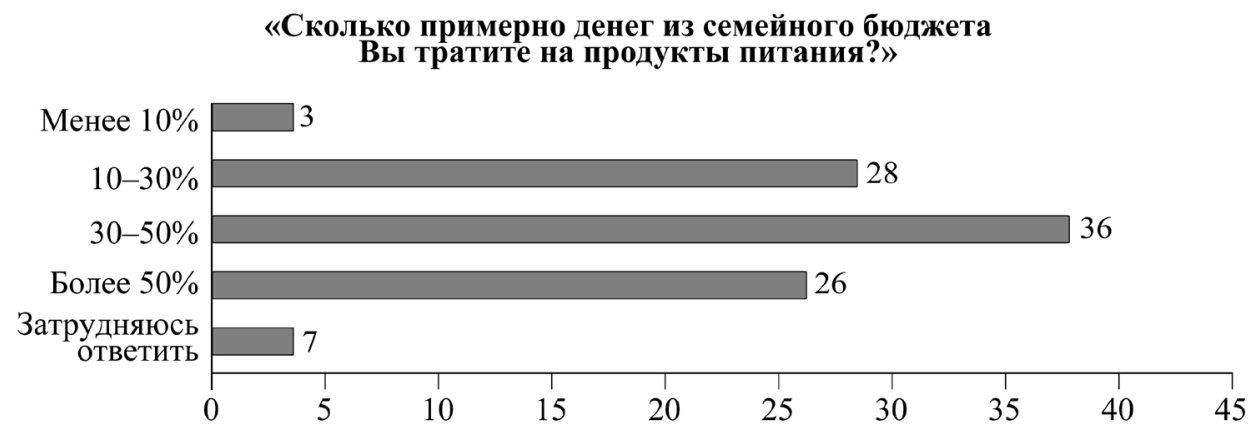

Рисунок 10. Доля расходов на продукты питания, \%, 2016 г.

\section{«Какая примерно часть суммарного месячного дохода} Вашей семьи обычно тратится на питание?»

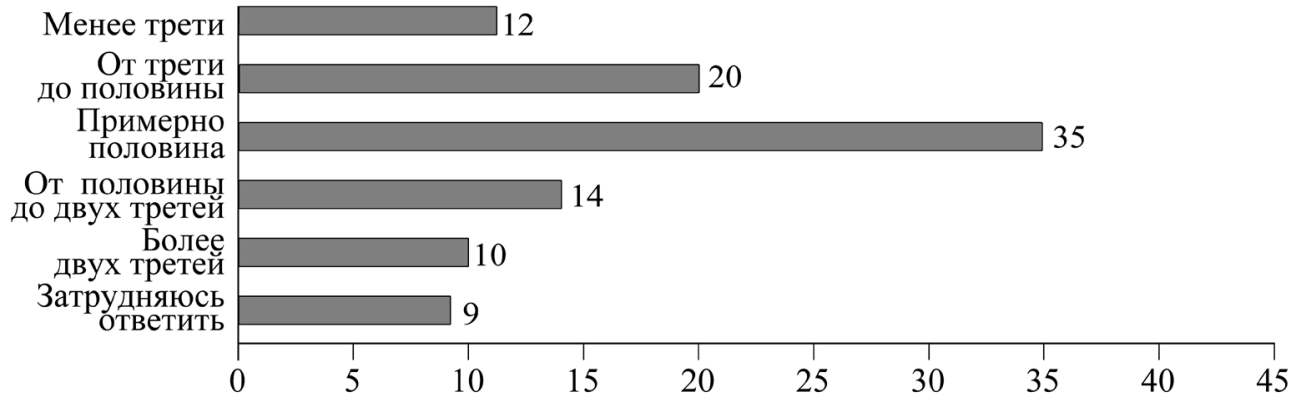

Рисунок 11. Доля расходов на продукты питания, \%, 2017 г.

Дело не только в том, что россияне тратят больше денег на продовольствие (по сравнению с 2016 г. в прошлом году 65\% стали тратить больше, и лишь у каждого четвертого расходы остались на том же уровне, хотя в 2016 г. эта группа расходов уже увеличилась: аналогичные показатели составили 72 и 20\%), а в том, что эти расходы растут на фоне устойчивых практик самообеспечения: в 2015-2016 гг. свыше 65\% респондентов уже выращивали овощи и фрукты на огороде (свыше $80 \%-$ картофель); но держал птицу или скотину лишь каждый пятый (преимущественно кур и уток). Отмечает рост цен на продукты питания в 2017 г. на 10-30\% каждый второй опрошенный (51\%), реже - менее чем на 10\% (12\%) или, наоборот, больше от 30 до 50\% (15\%). В качестве основной реакции на рост цен ${ }^{16}$ выступают поиск

16 В 2016 г. мы использовали вопрос-меню, и тогда основной реакцией на дальнейшее повышение цен было выращивание продуктов в больших объемах на огороде $(45 \%)$ и еще большие ограничения в покупке $(27 \%)$. В 2017 г. речь шла о реакции на уже произошедший рост цен, а используемые стратегии адаптации к этому росту оценивались с помощью набора шкал по каждой поведенческой стратегии (относится ли она к респонденту, не относится или он затрудняется ответить на вопрос). 
магазинов и рынков, где цены ниже (это стратегия 78\% респондентов), снижение объема покупок (так поступает каждый второй) или выбор более дешевых продуктов в привычных магазинах (68\%). На фоне этих стратегий тактики обращения к имеющим свой огород родственникам за продуктами (23\%) и выращивания больше овощей и фруктов на своем огороде или даче (40\%) явно отстают, видимо, потому, что эти возможности уже используются по максимуму в условиях, когда россияне в целом отказываются от ЛПХ (в пользу покупки продуктов питания в магазинах) в тех масштабах, которые были характерны для 1990-х гг. (рисунок 12, таблица 3) [Структура продукции сельского хозяйства по категориям хозяйств].

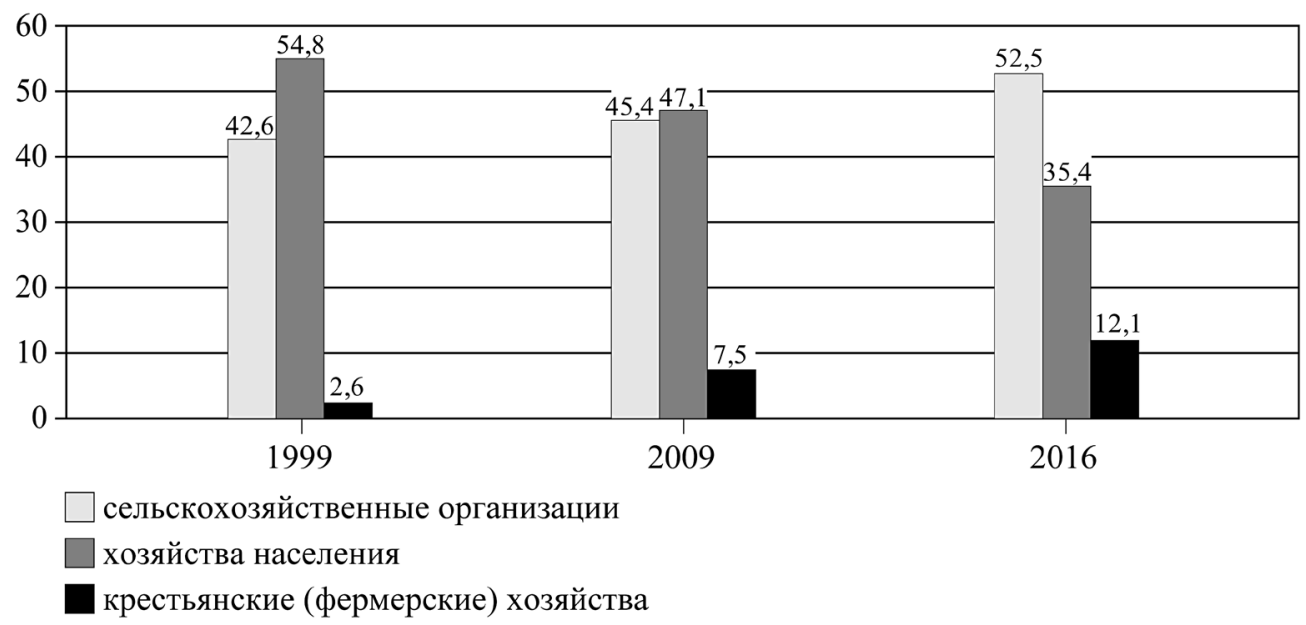

Рисунок 12. Структура российского сельского хозяйства, \%

Таблица 3. Производство основных видов сельскохозяйственной продукции по категориям хозяйств, \%, 2015 г.

\begin{tabular}{|l|c|c|c|}
\hline Виды продукции & Сельхозпредприятия & Хозяйства населения & $\begin{array}{c}\text { Крестьянские } \\
\text { (фермерские) хозяйства }\end{array}$ \\
\hline Зерно & 72,7 & 1 & 26,3 \\
\hline Сахарная свекла & 89 & 0,4 & 10,6 \\
\hline Семена подсолнечника & 70,3 & 0,4 & 29,3 \\
\hline Картофель & 13,8 & 77,6 & 8,6 \\
\hline Овощи & 17,9 & 67 & 15,1 \\
\hline Плоды и ягоды & 21,6 & 76,3 & 2,1 \\
\hline Скот и птица на убой & 74,4 & 22,7 & 2,9 \\
\hline Молоко & 47,8 & 45,6 & 6,6 \\
\hline Яйца & 78,4 & 20,7 & 0,9 \\
\hline
\end{tabular}


Впрочем, россияне в большинстве своем удовлетворены качеством питания: отличным его считал каждый десятый, хорошим - $45 \%$, удовлетворительным $39 \%$, а плохим - 5\%. Безусловно, в подобных вопросах следует принимать во внимание эффект социальной желательности и стремление показать себя живущим «на среднем уровне/нормально», однако самооценки свидетельствовали, что с рационом россиян все обстоит не так уж плохо (если не принимать во внимание приведенные выше цифры, показывающие, как дорого семьям обходится нормальное/ хорошее питание): каждый день или несколько раз в неделю едят мясо $84 \%$ (40\% и 44\% соответственно); несколько раз в неделю - рыбу (40\%), хотя каждый второй - реже одного раза в неделю $(50 \%)$; покупает свежие фрукты зимой каждую неделю $-55 \%$, несколько раз в месяц - $29 \%$ (но нужно учитывать разновидность фруктов (как правило, это бананы и мандарины), а также их качество). Однако, когда речь заходила о родных и знакомых, которые плохо питаются/недоедают, картина менялась: таких не оказалось у $65 \%$ опрошенных, тогда как $29 \%$ знали таких людей, и каждый второй из этой группы считал, что число плохо питающихся семей среди его друзей и знакомых за последние три года увеличилось (51\%) или осталось без изменений (41\%).

У читателя может возникнуть справедливый вопрос, почему результаты телефонного опроса представлены в виде простых частотных распределений, а не таблиц сопряженностей. Дело в том, что приведенные распределения ответов характерны для россиян независимо от возраста, пола и прочих характеристик, a встречающиеся различия носят точечный и предсказуемый характер: например, очевидно, что в беднейшей группе уровень экономической доступности продовольствия будет ниже, а доля расходов на него в семейном бюджете - выше. Или, скажем, по параметру места проживания (город и село) вполне предсказуемо, что при доминировании тех же поведенческих стратегий в условиях роста цен на продукты питания (поиск более дешевых продуктов или магазинов) у сельчан больше объективных возможностей для увеличения собственного производства на огороде, чем у дачников: согласно данным опроса, в 2017 г. по сравнению с 2016 г. $65 \%$ сельчан и $36 \%$ горожан стали выращивать на своих огородах больше овощей и фруктов, хотя в 2016 г. овощи или фрукты уже выращивали $87 \%$ сельчан и $56 \%$ горожан (преимущественно картофель - 84 и 79\% соответственно). В целом в обществе сохраняется разрыв в уровне доходов между городом и селом, поэтому сельчане чаще отвечали, что знают людей, которые плохо питаются/недоедают (35 против 27\% горожан), причем это устойчивая бедность, поскольку число плохо питающихся семей среди знакомых горожан за последние три года, скорее, увеличилось (54 против 44\% сельчан), а у жителей села, скорее, осталось без изменений (45 против 37\% горожан).

\section{Заключение}

В последние годы в государственном, медийном и научном дискурсах прочные позиции завоевало понятие «продовольственная безопасность»- термин, еще несколько лет назад способный смутить любого специалиста своим не вполне понятным содержанием и множеством коннотаций. Сегодня ситуация радикально 
изменилась, чему немало способствовали риторика импортозамещения в русле протекционистской государственной политики (ее суть - наращивание собственного агропроизводства) и продовольственное эмбарго, введенное в ответ на западные санкции. Однако обретенная этим термином «прописка» в официальной риторике отнюдь не делает его прозрачным: государственная политика достаточно противоречива, одни решения диктуются нестабильной внешнеполитической ситуацией, другие - требованиями внутреннего рынка и финансовыми возможностями властей; медийное освещение вопросов продовольственного обеспечения варьирует от безусловной поддержки государственных решений до критических оценок постсоветской экономической политики.

Одна из основных проблем научного анализа продовольственной безопасности заключается в том, что, как правило, ее базовые параметры задаются геополитическими и макроэкономическими соображениями и реалиями, тогда как, по сути, речь идет о рутинных практиках обеспечения домохозяйствами себя продуктами питания. Нередко второй аспект упускается из рассмотрения как незначимый, и рассуждения исследователей выстраиваются по условной формуле: государство/ крупные производители принимают определенные решения, населению приходится соответствующим образом выстраивать свои продовольственные практики и привычки. Подобная логика имеет право на существование, хотя «прыжки» с макроуровня на микроуровень часто вызывают у читателей такого типа работ сомнения, поскольку в макрополитическом и макроэкономическом контекстах они вряд ли слишком компетентны, а вот примеры из повседневности могут диссонировать с их личным опытом, учитывая региональную социально-экономическую дифференциацию российского пространства. Возможно, оптимальным форматом научных работ по продовольственной безопасности является четкая фокусировка либо на микроуровне рутинных практик продовольственного обеспечения домохозяйств, либо на макроуровне объективного политического и социально-экономического контекста, внутри которого россиянам приходится выстраивать, поддерживать или трансформировать эти практики.

С внутриэкономической точки зрения Россия вполне гарантировала себе продовольственную безопасность в том смысле, как она понимается в научной литературе (отсутствие голода и достаточное количество потребляемых калорий). Внутреннее измерение продовольственной безопасности крайне важно, потому что характеризует качество питания и общее состояние здоровья населения. И поскольку с 2000 г. калорийность и потребление продуктов питания выросли, можно уверенно говорить о продовольственной безопасности России с внутриэкономической точки зрения. С другой стороны, очевидны и внутриэкономические индикаторы продовольственной опасности: бедность домохозяйств ведет к сокращению потребления, и хотя в целом уровень бедности в стране снизился, примерно 18 млн россиян живут в бедности и питаются плохо, причем бедность непропорционально высока в сельских районах, но городские домохозяйства более подвержены риску продовольственной опасности ввиду отсутствия у них земельных участков.

В России разработан целый ряд методических решений для оценки продовольственной безопасности, прежде всего с опорой на статистические макропоказатели. В то же время предпринимаются социологические попытки оценивать самочувствие потребителей, исходя в первую очередь из официальных государственных трактовок продовольственной безопасности, т.е. замеряются объективные 
социально-экономические (и инфраструктурные) возможности населения в приобретении продовольствия (и непродовольственных товаров), а также предпочтения потребителей (скажем, выбор российского или иностранного продукта при прочих равных их характеристиках). Большинство исследований (репрезентативные опросы) представляют собой обобщенные оценки восприятия населением государственных решений и их последствий в сфере продовольственной безопасности, но изредка встречаются и проекты в рамках качественного подхода, фиксирующие типовые стратегии выживания (прежде всего самых бедных - сельских) домохозяйств, а не устойчивые поведенческие паттерны продовольственного (само)обеспечения.

Сегодня мы располагаем либо точечными детальными описаниями повседневных практик в отдельных типах поселений (кейсы), либо общенациональными опросными данными, не отражающими региональную и локальную специфику. Для преодоления ограничений существующих методических решений мы предлагаем комплексный инструментарий социологического мониторинга, который включает в себя анкету телефонного опроса и гайд полуформализованного экспертного интервью, поскольку, на наш взгляд, оптимальной стратегией мониторинга продовольственной безопасности являются корректный учет и переход от сугубо экономических категорий (низкий/высокий уровень потребления, структура расходов домохозяйств и пр.) к социологическим (субъективные оценки и повседневные практики), при этом мы признаем, что высокая доля расходов домохозяйств на продовольствие и достижение рекомендованных норм питания становятся источником социальной нестабильности. Тогда риски продовольственной безопасности по оценкам известных экономистов и простых респондентов совпадут: россияне, выбирая варианты ответов на задаваемые вопросы (например, о дороговизне продуктов питания), фактически будут говорить об экономической недоступности полноценного питания.

Несмотря на неоднозначное состояние продовольственной сферы России в последние несколько лет, обусловленное и экономическими трудностями внешнеполитического характера, и решительными действиями российского руководства по модернизации и развитию отечественного агрокомплекса, население вполне консолидированно и неизменно поддерживает политические решения правительства. Вместе с тем россияне подтверждают, что были вынуждены «затянуть пояса», тратя большую долю семейного бюджета на продукты и стараясь экономить на наиболее дорогостоящих и питательных составляющих рациона (мясо, рыба и фрукты). Фактически уже три года (длительность нашего мониторинга) население честно признается в форсировании приспособительных стратегий претерпевания социально-экономических трудностей через экономию на продовольствии и интенсификацию самообеспечения - выращивание большего количества овощей и фруктов в ЛПХ (и на огородах).

\section{Литература}

Алтухов А., Вермель Д. (1997) Продовольственное самообеспечение страны: состояние и перспективы // АПК: экономика, управление. № 11. С. 18-24. 
Барсукова С., Коробкова А. (2014) Вступление России в ВТО в зеркале российских печатных СМИ // Экономическая социология. № 4. С. 20-40.

Бондаренко Л.В. (1998) Тенденции в потреблении сельского населения // Экономика сельскохозяйственных и перерабатывающих предприятий. № 3. С. 38-41.

Вегрен С., Троцук И.В. (2013) Продовольственная безопасность в Российской Федерации // Никулин А.М., Пугачева М.Г., Шанин Т. (ред.) Крестьяноведение. Теория. История. Современность. Ученые записки. Вып. 8. М.: Дело. С. 270-301.

Виссер О., Мамонова Н., Споор М., Никулин А. (2015) Тихий продовольственный суверенитет среди громкой продовольственной безопасности // Никулин А.М., Пугачева М.Г., Шанин Т. (ред.) Крестьяноведение: Теория. История. Современность. Ученые записки. Вып. 10. М.: Дело. С. 10-35.

Доходы, расходы и потребление домашних хозяйств (по итогам выборочного обследования бюджетов домашних хозяйств) (2016). М.: Росстат.

Киселев С.В. (2013) Основные проблемы мировой продовольственной безопасности // Киселев С.В. (ред.) Мировой продовольственный кризис и продовольственная безопасность России: Сб. ст. М.: РГ-Пресс. С. 7-10.

Крылатых Э.Н. (2014) Концепции и методологические основы изучения продовольственной безопасности // Никоновские чтения. № 19. С. 3-5.

Милехин А. (2017) При первых тревожных сигналах народ делает запасы // Газета.ru // https://www.gazeta.ru/business/2017/02/21/10537373.shtml

О мониторинге и состоянии продовольственной безопасности Российской Федерации (2012) // Экономика сельскохозяйственных и перерабатывающих предприятий. № 2. C. $15-20$.

О перечне показателей в сфере обеспечения продовольственной безопасности РФ. Распоряжение Правительства РФ от 18 ноября 2013 г. №2138-р // Российская газета. 22 ноября 2013 г. // https://rg.ru/2013/11/22/prod-bezop-site-dok.html

О соотношении денежных доходов населения с величиной прожиточного минимума и численности малоимущего населения в целом по РФ в IV квартале 2016 г. // Федеральная служба государственной статистики РФ // http://www.gks.ru/bgd/free/b04_03/IssWWW. exe/Stg/d02/65.htm

Об утверждении Рекомендаций по рациональным нормам потребления пищевых продуктов, отвечающим современным требованиям здорового питания. Приказ Министерства здравоохранения и социального развития РФ от 19 августа 2016 г. №614 // Garant. ru // http://www.garant.ru/products/ipo/prime/doc/71385784/

Овчарова Л.Н., Бирюкова С.С., Тер-Акопов С.А., Барданян Е.Г. (2014) Что изменилось в доходах, расходах и потреблении российского населения? М.: ВШЭ.

Покупка продуктов и экономия: На каких продуктах и товарах люди экономят? // Фонд «Общественное мнение»// http://fom.ru/Ekonomika/13193

Послание Президента Российской Федерации В.В. Путина Федеральному собранию от 12 декабря 2012 г. // Сайт Президента России // http://www.kremlin.ru/news/17118

Потребительское поведение россиян в условиях кризиса: Какие стратегии потребительского поведения выбирают россияне в кризис? (2015) // Фонд «Общественное мнение» // http://fom.ru/Ekonomika/12100

Потребление продуктов питания в домашних хозяйствах в 2015 г. (2016) М.: Росстат.

Потребление основных продуктов питания населением Российской Федерации (2016) // Федеральная служба государственной статистики РФ // http://www.gks.ru/wps/wcm/ connect/rosstat_main/rosstat/ru/statistics/publications/catalog/doc_1286360627828

Продовольственное эмбарго: итоги 2015 года (2016) // Аналитический центр при Правительстве РФ // http://ac.gov.ru/files/publication/a/8972.pdf

Продовольственные контрсанкции России: за и против (2015) // ВЦИОМ // https://wciom.ru/index.php?id=236\&uid=115517

Продуктовое эмбарго привело к росту цен и убивает конкуренцию (2015) // Газета.ru // https://www.gazeta.ru/business/news/2015/08/12/n_7454857.shtml

Сельскохозяйственная деятельность хозяйств населения в России (1999). М.: Госкомстат.

Социально-экономические индикаторы бедности в 2013-2016 гг. (2017) М.: Росстат. 
Стратегия национальной безопасности Российской Федерации до 2020 г. (2009) // Российская газета. 19 мая 2009 г. // https://rg.ru/2009/05/19/strategia-dok.html

Структура продукции сельского хозяйства по категориям хозяйств // Федеральная служба государственной статистики РФ // http://www.gks.ru/free doc/new site/business/sx/tab-sel2.htm

Фомичев С.Н., Ковшов А.С. (2010) Региональный аспект продовольственной безопасности России // Наука и современность. № 3. С. 170-171.

Шагайда Н.И., Узун В.Я. (2015) Продовольственная безопасность в России: мониторинг, тенденции и угрозы. М.: Дело.

Ayres J., Bosia M.J. (2011) Beyond Global Summitry: Food Sovereignty as Localized Resistance to Globalization // Globalizations, no 8, pp. 47-63.

Claeys P. (2013) An Overview of La Via Campesina's Right-Based Claims over the Last 20 Years. Paper for the Conference "Food Sovereignty: A Critical Dialogue", Yale University/ISS.

Declaration of Nyéléni. 27 February 2007. Selingué Mali (2007) // Nyéléni Newsletter // http://www.nyeleni.org/spip.php?article290

Global Food Security Index 2015: An Annual Measure of the State of Global Food Security, London: Economist Intelligence Unit.

Global Food Security Index 2016: An Annual Measure of the State of Global Food Security, London: Economist Intelligence Unit.

Hendriks S. (2015) The Food Security Continuum: A Novel Tool for Understanding Food Insecurity as a Range of Experiences // Food Security, no 7, pp. 609-619.

Matthews M. (1986) Poverty in the Soviet Union: The Lifestyles of the Underprivileged in Recent Years, Cambridge University Press.

McMichael M. (2009) Food Sovereignty, Social Reproduction and the Agrarian Question // Peasants and Globalization. Political Economy, Rural Transformation and the Agrarian Question (eds. Akram-Lodhi A.H., Kay C.), New York: Routledge, pp. 288-312.

Patel R. (2009) What Does Food Sovereignty Look Like? // Journal of Peasant Studies, no 36, pp. 663-706.

Piontak J.R., Schulman M.D. (2014) Food Insecurity in Rural America // Contexts, no 13, pp. $75-77$.

Scott J.C. (1985) Weapons of the Weak: Everyday Forms of Peasant Resistance, New Haven: Yale University Press.

Sedik D., Sotnikov S., Weismann D. (2003) Food Security in the Russian Federation, Rome: FAO.

The Soviet Agro-Food System and Agricultural Trade: Prospects for Reform (1991), Washington: OECD.

The State of Food Insecurity in the World 2015 (2015) // Food and Agriculture Organization of the United Nations // http://www.fao.org/3/a-i4646e.pdf

Wegren S.K., Nikulin A., Trotsuk I. (2017) The Russian Variant of Food Security // Problems of Post-Communism, vol. 64, no 1, pp. 47-62.

Willis K. (1985) Klass: How Russians Really Live, New York: St. Martin’s Press.

World Development Report 2008: Agriculture for Development (2008) // The World Bank // http://documents.worldbank.org/curated/en/587251468175472382/World-developmentreport-2008-agriculture-for-development 


\title{
Interpretations and Dimensions of Food Security in Contemporary Russia: Discursive and Real Contradictions
}

\author{
I. TROTSUK*, A. NIKULIN**, S. WEGREN***
}

\begin{abstract}
*Irina Trotsuk - Doctor of Science in Sociology, Senior Researcher, Center for Agrarian Studies, Russian Presidential Academy of National Economy and Public Administration; Associate Professor, Sociology Chair, RUDN University. Address: 82, Avenue Vernadskogo, Moscow, 119571, Russian Federation. E-mail: irina.trotsuk@yandex.ru

**Alexander Nikulin - Candidate of Science in Economics, Head, Center for Agrarian Studies, Russian Presidential Academy of National Economy and Public Administration. Address: 82, Avenue Vernadskogo, Moscow, 119571, Russian Federation. Email: nikulin@ ranepa.ru

$* * *$ Stephen Wegren - Professor of Political Science, Southern Methodist University. Address: Dallas, Texas, 75275, USA. E-mail: swegren@smu.edu
\end{abstract}

Citation: Trotsuk I., Nikulin A., Wegren S. (2018) Interpretations and Dimensions of Food Security in Contemporary Russia: Discursive and Real Contradictions. Mir Rossii, vol. 27, no 1, pp. 34-64 (in Russian). DOI: 10.17323/1811-038X-2018-27-1-34-64

\begin{abstract}
This article considers the reasons and consequences of the increased attention from politicians and scholars to the challenges of national and global food security. First, the authors focus on the contradictory definitions of food security in intellectual and ideological debates which determine the development of national and global doctrines of food security (and 'food sovereignty' as its critical alternative). Secondly, the authors consider past and present attempts to ensure food security and identify the historical zigzags of food policies in Russia (from the Soviet autarchic policy of food self-sufficiency to attempts to liberalize food security definitions in the 1990s, and the new protectionist and autarchic food security doctrine of the 2000s). The authors also present a range of common indicators of food security, and emphasize that the gross growth in the production of various types of food is insufficient to assess the quality of national food policies. The key indicators of food security include the effectiveness of agricultural production, access to quality food for all social groups, and the potential of consumers to control the issues of national food security. Finally, the authors consider the sociological approach to the study of food security and present data from a series of sociological monitoring developed and conducted by the Center for Agrarian Studies of RANEPA 2015-2017. The analysis identified the 'double autarchy' in the responses of respondents: on the one hand, they support the general political course on food protectionism and nationalism (state autarchy), while, on the other, they strive to implement a micro-policy of autonomous food sovereignty (family autarchy) by intensifying household efforts to ensure natural self-sufficiency.
\end{abstract}

Key words: food security, liberalism, protectionism, social differentiation, access to food, regional differences 


\section{References}

Altukhov A., Vermel D. (1997) Prodovol'stvennoe samoobespechenie strany: sostoyanie i perspektivy [Food Self-Sufficiency of the Country: The Current State and Prospects]. APK: ekonomika, upravlenie, no 11, pp. 18-24.

Ayres J., Bosia M.J. (2011) Beyond Global Summitry: Food Sovereignty as Localized Resistance to Globalization. Globalizations, no 8, pp. 47-63.

Barsukova S., Korobkova A. (2014) Vstuplenie Rossii v VTO v zerkale rossijskikh pechatnykh SMI [The Entry of Russia in the WTO in the Perceptions of Russian Print Media]. Ekonomicheskaya sotsiologiya, no 4, pp. 20-40.

Bondarenko L.V. (1998) Tendentsii V potreblenii sel'skogo naseleniya [The Trends in the Consumption of Rural Population]. Ekonomika sel'skokhozyajstvennykh i pererabatyvayushchikh predpriyatij, no 3, pp. 38-41.

Claeys P. (2013) An Overview of La Via Campesina's Right-Based Claims over the Last 20 Years. Paper for the Conference "Food Sovereignty: A Critical Dialogue", Yale University/ISS.

Declaration of Nyéléni. 27 February 2007. Selingué Mali (2007). Nyéléni Newsletter. Available at: http://www.nyeleni.org/spip.php?article290, accessed 31 October 2017.

Dokhody, raskhody i potreblenie domashnikh khozyajstv (po itogam vyborochnogo obsledovaniya byudzhetov domashnikh khozjajstv) (2016) [Incomes, Expenditures, and Consumption of Households (Based on the Results of a Sample Survey of Households' Budgets)], Moscow: Rosstat.

Fomichev S.N., Kovshov A.S. (2010) Regional'nyj aspekt prodovol'stvennoj bezopasnosti Rossii [The Regional Aspect of Russian Food Security]. Nauka i sovremennost', no 3, pp. 170-171.

Global Food Security Index 2015: An Annual Measure of the State of Global Food Security, London: Economist Intelligence Unit.

Global Food Security Index 2016: An Annual Measure of the State of Global Food Security, London: Economist Intelligence Unit.

Hendriks S. (2015) The Food Security Continuum: A Novel Tool for Understanding Food Insecurity as a Range of Experiences. Food Security, no 7, pp. 609-619.

Kiselev S.V. (2013) Osnovnye problemy mirovoj prodovol'stvennoj bezopasnosti [The Key Problems of the Global Food Security]. Mirovoj prodovol'stvennyj krizis i prodovol stvennaya bezopasnost' Rossii [The World Food Crisis and the Food Security in Russia] (ed. Kiselev S.V.), Moscow: RG-Press, pp. 7-10.

Krylatyh E.N. (2014) Kontseptsii i metodologicheskie osnovy izucheniya prodovol'stvennoj bezopasnosti [The Concepts and Methodological Grounds for the Study of Food Security]. Nikonovskie chteniya, no 19, pp 3-5.

Matthews M. (1986) Poverty in the Soviet Union: The Lifestyles of the Underprivileged in Recent Years, Cambridge University Press.

McMichael M. (2009) Food Sovereignty, Social Reproduction and the Agrarian Question. Peasants and Globalization. Political Economy, Rural Transformation and the Agrarian Question (eds. Akram-Lodhi A.H., Kay C.), New York: Routledge, pp. 288-312.

Milekhin A. (2017) Pri pervykh trevozhnykh signalakh narod delaet zapasy [People Rushing to Make Reserves at the First Signs of Alarm]. Gazeta.ru. Available at: https://www.gazeta.ru/business/2017/02/21/10537373.shtml, accessed 31 October 2017.

O monitoringe i sostoyanii prodovol'stvennoj bezopasnosti Rossijskoj Federatsii (2012) [On the Monitoring of Food Security in the Russian Federation]. Ekonomika sel'skohozyajstvennykh i pererabatyvayushchikh predpriyatij, no 2, pp. 15-20.

$\mathrm{O}$ perechne pokazatelej $\mathrm{v}$ sfere obespecheniya prodovol'stvennoj bezopasnosti RF. Rasporyazhenie Pravitel'stva RF ot 18 noyabrya 2013 g. №2138-r [On the List of Indicators in the Area of Food Security of the Russian Federation. The Decree of the RF Government of November 18, 2013 No. 2138-R]. Rossijskaya gazeta. 22 November 2013. Available at: https://rg.ru/2013/11/22/prod-bezop-site-dok.html, accessed 31 October 2017.

O sootnoshenii denezhnykh dokhodov naseleniya s velichinoj prozhitochnogo minimuma i chislennosti maloimushchego naseleniya v tselom po RF v IV kvartale 2016 g. (2016) 
[On the Ratio of Incomes of the Population with a Subsistence Minimum and the Number of Poor People in the Whole in Russia in the IV Quarter of 2016]. Federal State Statistics Service of the Russian Federation. Available at: http://www.gks.ru/bgd/free/b04_03/ IssWWW.exe/Stg/d02/65.htm, accessed 31 October 2017.

Ob utverzhdenii Rekomendatsij po ratsional'nym normam potrebleniya pishchevykh produktov, otvechayushchim sovremennym trebovaniyam zdorovogo pitaniya. Prikaz Ministerstva zdravookhraneniya i sotsial'nogo razvitiya RF ot 19 avgusta 2016 g. №614 [On the Approval of Recommendations on the Rational Norms of Food Consumption that Meet the Modern Requirements of a Healthy Diet. Order of the Ministry of Health and Social Development of the Russian Federation dated August 19, 2016 No. 614]. Garant.ru. Available at: http://www.garant.ru/products/ipo/prime/doc/71385784/, accessed 31 October 2017.

Ovcharova L.N., Biryukova S.S., Ter-Akopov S.A., Bardanyan E.G. (2014) Chto izmenilos'v dokhodakh, rashodakh i potreblenii rossijskogo naseleniya? [What Has Changed in the Incomes, Expenses, and Consumption of the Russian Population?], Moscow: HSE.

Patel R. (2009) What Does Food Sovereignty Look Like? Journal of Peasant Studies, no 36, pp. 663-706.

Piontak J.R., Schulman M.D. (2014) Food Insecurity in Rural America. Contexts, no 13, pp. 75-77.

Pokupka produktov i ekonomiya: Na kakikh produktakh i tovarakh lyudi ekonomyat? [Purchases and Saving: What are the Products and Goods on Which People Save?]. Fond "Obshchestvennoe mnenie». Available at: http://fom.ru/Ekonomika/13193, accessed 31 October 2017.

Poslanie Prezidenta Rossijskoj Federatsii V.V. Putina Federal'nomu sobraniyu ot 12 dekabrya 2012 g. [The Address of the President V.V. Pution to the Russian Federation to the Federal Assembly on December 12, 2012]. Website of the President of the Russian Federation. Available at: http://www.kremlin.ru/news/17118, accessed 31 October 2017.

Potrebitel'skoe povedenie rossiyan v usloviyakh krizisa: Kakie strategii potrebitel'skogo povedeniya vybirayut rossiyane v krizis? (2015) [The Consumer Behavior of Russians During the Crisis: What Strategies Do Russians Choose?]. Fond "Obshchestvennoe mnenie». Available at: http://fom.ru/Ekonomika/12100, accessed 31 October 2017.

Potreblenie osnovnykh produktov pitaniya naseleniem Rossijskoj Federatsii (2016) [The Consumption of Basic Food Produce in the Population of the Russian Federation]. Federal State Statistics Service of the Russian Federation. Available at: http://www.gks.ru/wps/wcm/connect/rosstat main/rosstat/ru/statistics/publications/ catalog/doc_1286360627828, accessed 31 October 2017.

Potreblenie prodūktov pitaniya $v$ domashnikh khozyajstvakh v $2015 \mathrm{~g}$. (2016) [The Consumption of Food Products in Households in 2015], Moscow: Rosstat.

Prodovol'stvennoe embargo: itogi 2015 goda (2016) [The Food Embargo: the Results in 2015]. Analytical Center for the Government of the Russian Federation. Available at: http://ac.gov.ru/files/publication/a/8972.pdf, accessed 31 October 2017.

Prodovol'stvennye kontrsanktsii Rossii: za i protiv (2015) [Russia's Food Counter Sanctions: the Pros and Cons]. Russian Public Opinion Research Center. Available at: https://wciom.ru/index.php?id=236\&uid=115517, accessed 31 October 2017.

Produktovoe embargo privelo $k$ rostu tsen i ubivaet konkurentsiyu (2015) [Food Embargo Led to Higher Prices and Killing Competition]. Gazeta.ru. Available at: https://www.gazeta.ru/business/news/2015/08/12/n_7454857.shtml, accessed 31 October 2017.

Scott J.C. (1985) Weapons of the Weak: Everyday Forms of Peasant Resistance, New Haven: Yale University Press.

Sedik D., Sotnikov S., Weismann D. (2003) Food Security in the Russian Federation, Rome: FAO.

Sel'skohozyajstvennaya deyatelnost'khozyajstv naselenija v Rossii (1999) [Agricultural Activities of Households in Russia], Moscow: Goskomstat.

Shagajda N.I, Uzun V.Ya. (2015) Prodovol'stvennaya bezopasnost'v Rossii: monitoring, tendentsii i ugrozy [Food Security in Russia: Monitoring, Trends, and Threats], Moscow: Delo.

Sotsial'no-ekonomicheskie indikatory bednosti v 2013-2016 gg. (2017) [Social-economic Indicators of Poverty], Moscow: Rosstat.

Strategiya natsional'noj bezopasnosti Rossijskoj Federatsii do 2020 g. (2009) [The National Security Strategy of the Russian Federation until 2020]. Rossijskaya gazeta. 19 May 2009. Available at: https://rg.ru/2009/05/19/strategia-dok.html, accessed 31 October 2017. 
Struktura produktsii sel'skogo khozyajstva po kategoriyam khozyajstv [The Structure of Agricultural Products by Categories of Farms].Federal State Statistics Service of the Russian Federation. Available at: http://www.gks.ru/free_doc/new_site/business/sx/tabsel2.htm, accessed 31 October 2017.

The Soviet Agro-Food System and Agricultural Trade: Prospects for Reform (1991), Washington: OECD.

The State of Food Insecurity in the World 2015 (2015). Food and Agriculture Organization of the United Nations. Available at: http://www.fao.org/3/a-i4646e.pdf, accessed 31 October 2017.

Visser O., Mamonova N., Spoor M., Nikulin A. (2015) Tikhij prodovol'stvennyj suverenitet sredi gromkoj prodovol'stvennoj bezopasnosti [The Quiet Food Sovereignty under the Loud Food Security]. Krest'yanovedenie. Teoriya. Istoriya. Sovremennost'. Uchenye zapiski. Vyp. 10 [Peasant Studies. Theory. History. Modernity. Academic notes. Issue 10] (eds. Nikulin A.M., Pugacheva M.G., Shanin T.), Moscow: Delo, pp. 10-35.

Wegren S.K., Nikulin A., Trotsuk I. (2017) The Russian Variant of Food Security. Problems of Post-Communism, vol. 64, no 1, pp. 47-62.

Wegren S., Trotsuk I.V. (2013) Prodovol'stvennaya bezopasnost' v Rossijskoj Federatsii [Food Security in the Russian Federation]. Krest'yanovedenie. Teoriya. Istoriya. Sovremennost'. Uchenye zapiski. Vyp. 8 [Peasant Studies. Theory. History. Modernity. Academic notes. Issue 8] (eds. Nikulin A.M., Pugacheva M.G., Shanin T.), Moscow: Delo, pp. 270-301.

Willis K. (1985) Klass: How Russians Really Live, New York: St. Martin's Press.

World Development Report 2008: Agriculture for Development (2008). The World Bank. Available at: http://documents.worldbank.org/curated/en/587251468175472382/Worlddevelopment-report-2008-agriculture-for-development, accessed 31 October 2017. 